University of Rhode Island

DigitalCommons@URI

Open Access Master's Theses

1960

\title{
THE INFLUENCE OF AMERICAN COMMERCIAL INTERESTS IN CHINA UPON UNITED STATES POLICY TOWARD JAPAN,
} 1937-1938

Robert J. Colborn Jr.

University of Rhode Island

Follow this and additional works at: https://digitalcommons.uri.edu/theses

\section{Recommended Citation}

Colborn, Robert J. Jr., "THE INFLUENCE OF AMERICAN COMMERCIAL INTERESTS IN CHINA UPON UNITED STATES POLICY TOWARD JAPAN, 1937-1938" (1960). Open Access Master's Theses. Paper 1800.

https://digitalcommons.uri.edu/theses/1800

This Thesis is brought to you for free and open access by DigitalCommons@URI. It has been accepted for inclusion in Open Access Master's Theses by an authorized administrator of DigitalCommons@URI. For more information, please contact digitalcommons-group@uri.edu. 
THE IHTLUENGE OF AMERICAN CONHERCTAL INTERESTS

IN CHINA UPON UNITED STATES POLICI

TOWARD JAPAK, 1937-1938

BI

ROBERT J. COLBORN, JK.

A THESIS SUBMTTHE IN PARTIAL FULPILLMEN OF THE REQUIRIMEWIS FOR THE DEGRER OF

MASTKR OF ARTS

IN

HISTORY

UMIVIRSITY OR RHODE ISLAND

1960 


\section{ACKNOWLEDGMENS}

The author wishes to express his gratitude to Dr.

Donald E. Smith for his many schoiarly suggestions while the preparation of this thesis was in progress. The courteous assistance of the library staff of the University of Rhode Island is also deeply appréciated. 


\section{ABSTRACT}

The purpose of this theais is to investigate the degree of influence which American business interests in China exerted upon United States policy toward Japan during the period 1937-1938. On the night of July 7, 1937, Japanese military forces invaded the Republic of China without a prior declaration of war. During the months of undeclared but unrestrained war which followed, foreign investments in the trade and industry of China were threatened with extinction. As hostilities became more widespread, business activity within China was brought to a virtual standstill, and properties owned by foreign comrercial groups frequently suffered extensive damage. The Japanese Government, moreover, made deliberate efforts to force the withdrawal of all foreign industry and trade from thase areas of China under its control.

American business interests in China condemned Japan's war of aggression and called upon the United States Government to defend the commercial rights which were guaranteed by the Open Door policy. Throughout 1937 and 1938, the commerclal groups in China insisted that the government in Washington adopt more spirited measures against the Japanese. The business commuity was well organized and succeeded in keeping its observations and opinions 
regarding developments in China before the American

Government and the American people. This study will investigate the role which American business interests sought to play in the formulation of United States policy toward Japan.

A most valuable source of primary materials was provided by Volume I of the Foreign Relations of the United States: Japan, 1931-1941, a compilation of diplomatic papers published by the Department of State in 1943. The China Weekly Review, an English language newspaper published in Shanghai, reflected the attitude of American citizens resident in China during 1937 and 1938. The Commercial and Financial Chronicle, a leading commercial journal, indicated the opinion of businessmen in the United States toward the war in East Asia. The Congressional Record revealed what was being thought on Capitol Hill in the period 1937-1938. Henry L. Stimson's On Active Service in Peace and War, Joseph C. Grew's Ten Years in Japan, and The Memoirs of Cordell Hull, provided valuable insights into United States foreign policy.

Several secondary sources were of special value in this study. John W. Masland's "Commercial Influence Upon Far Eastern Policy," published in the Pacific Historical Review, must be rated as of primary importance. An excellent survey of the nature and value of American commerce in China was presented in Miriam S. Farley's "America's Stake in the Far East," which appeared in Far 
Eastern Survey in 1936. Other noteworthy secondary sources were A. Whitney Griswold's The Far Lastern Policy of the United States, William C. Johnstone's The United States and Japan's New Order, and Robert E. Osgood's Ideals and SelfInterest in America's Foreign Relations.

The major finding of this study is that American commercial interes's in China did exert an ultimate influence upon United States policy toward Japan. This influence, however, was indirect and overshadowed by the broader concerns of Arerican national self-interest. Although the American Government came to the defense of the Open Door in China during 1937 and 1938, it was not motivated by any intrinsic desire to preserve Sino-American economic relations. The United States Government and public opinion in general had never considered the China trade to be of vital national importance. But in 1937 American statesmen were vitally interested in obstructing Japan's efforts to create a "new order" in Last Asla. It was to thwart Japan that the United States upheld the Open Door, and not because of any inherent desire to sustain American commercial interests in China.

Although the business comunity was unsuccessful in its attempts to influence American policy directly, there is a sense in which the commercial interests in China did affect the subsequent course of Japanese-American relations. The repeated destruction of American Iives and properties by the Japanese gradually angered the people of the United 
States. As public resentment grew, the American Government was given increased latitude in its efforts to deter Japanese imperialism in East Asta. It is in this way that the violation of American commercial rights in China was to have an ultimate Influence upon United States policy in East Asia. 
TABLE OF CONTENTS

Page

ACKNOWLEDGMENWS

Chapter

I. INTRODUCTION AND HISTORICAL BAGKGROUND . . 1

Early Diplomatic and Commerclal Relation:

$1784-1900$

The Doctrine of the Open Door

The Open Door and Sino-Amertican Eeonomic Relations, 1900-1931

The Rivalry of Japan and the United States in East Asia

II. AMERICAN COMMHATAL INTERESTS IN CHINA,

$1931-1937 \ldots \ldots \ldots 24$

The Manchurian Crisis and United States Polley

The Open Door Closes in Manchuria

New Threats to the Open Door, 1934-1936

Sino-Ameriean Econonic Relationg on the Eve of War

III. THE STNO-JAPANESE WAR, 1937-1938t THE CHALIENGE TO AMERICAN IHTERESTS IH CHIHA ......44

Japan Invades Chine, 1937 Japan's Polley of Comperelal Exclusion in China

Effects of the War on Sino-Amerlean Trade

Reaction of the American Business Community to Japanese Aggression

Reaction of the United States Government to Japanese Aggression

IV. THE IMPACT OF AMERICAN COMMERCIAL IMTERESTS ON UNITED STATES POLICY: AN ASSESSMENT * 80

Comercial Interest in Relation to Major Political Fretors

Commercial Interests in Relation to Major Economic Factore 
Chapter

Page

V. SURMARY AND COMCLUSION ........... 104 BIBLIOGRAPHY . . . . . . . . ....... 113 
CHAPTER I

INTRODUCTION AND HISTORICAL BACKGROUND

Early Diplomatic and Commercial Relations, 1784-1900

Since the earliest days of the American Republic,

American merchants have carried on commercial relations with China. The voyage of the Empress of China in 1784 marked the first time an American ship had sailed directly to Canton, the center of the early China trade. I Mithin thirty years, Canton was the site of a growing community of resident American commercial agents. 2 .

Like the European traders who proceeded them, American merchants sought the exotic products of the ancient Celestial Kingdom. The early China clippers brought back silks, spices, and tea, which were paid for largely in specie. This early trade, though small in volume, was of considerable importance to a youthful and small maritime nation which in its early years depended heavily upon foreign trade and shipping for its livelihood.3 Although many

$1_{\text {paul H. Clyde, The Far East: A History of the }}$ Impact of the dest on Eastern Ásia (New York: PrenticeHal1, Inc., 1948), p. 127.

2Julien Arnold, China: A Commercial and Industrial Handbook, U.S. Dept. of Commerce Trade Promotion Series No. 28 Tashington: U.S. Government Printing office, $1926)$, p. 139.

3 Miriam S. Farley, "America's Stake in the Far East, I: Trade," Far Eastern Survey, V (July 29, 1936), 162. 
Americans interested in the Far Eastern trade considered China to be the ost valuable Asian market, their considerations were based mainly on the hope of future developments rather than upon present accomplishments. 4 This emphasis uron the potential trade with China rather than its actualities was to be a constantly recurring theme in Chinese-American relations.

The first American merchants conducted their trade with a larger measure of individual freedom than did the British, their chief rivals. Americans, however, did not enjoy the financial backing or the prestige of the English East India Company, nor did they have the naval protection of their government. As long as the early American trader felt that he enjoyed equal trading terms with the British, there was little agitation for the oficial support of the authorities in lashington. But as relations grew more strained between the British and the Chinese Government after 1834, this early indifference to offlcial support gave way. 5

Then the Chinese gave indication in 1839 that they would work to limit the volume of Foreign trade at Canton, then the only Chinese port open to foreign conmerce, the American businessmen of that city petitioned the United

4rilliam L. Neumann, "Arnbiguity and Ambivalence in Ideals of National Interest in Asia," Isolation and Security, ed. Alexander DeConde (Durham, North Carolina: Duke University Press, 1957), p. 151.

5 Clyde, p. 127. 
States Congress to send a comercial agent who was authorized to conclude a treaty of commerce. Furthermore, they requested a naval force adequate to protect American citizens and property. It was during this period of worsening Anglo-Chinese relations that the attention of the American Government and American citizens was turned upon the embryonic comerce at far away Canton. 6

Before the American Goverrment felt constrained to act, however, the first of a series of wars which were to prove fatal to China's sovereignty took place. The occasion for the first armed clash between China and a western power was the illegal traffic in opiun wilich Great Britain had been engaging in. The unprecedented growth of this trade in the years immediately prior to hostilities produced serious consequences for China. To pay for this vastly increased importation in opium the chinese Government had been forced to export silver, rach to the nation's economic detriment. The efforts of China to curtail this trade provided the cause for war.?

The so-called Opium War (1839-1842) between Great Britain and the Chinese Empire ended disastrously for the already enervated celestial Kingdom of the Hanchus. Helpless before the superior strength of a "barbarous" nation, China was forced to sue for peace rith Great Britain. The days of China's exclusiveness and supertority were at an end. The next hundred years would see increasingly

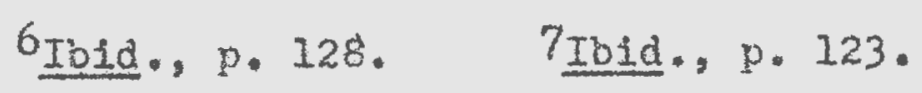


voracious foreign intruders dictate the terms under which China might enjoy trade and peace.8

The Treaty of Nanking (1842) which officially ended the oplum filar, and a supplementary treaty signed a year later, set the basic principles which were "to govern China's international status for a century." 9 China was forced to open new ports to forelgn commerce, agreed to a uniform and moderate tariff, provided for extraterritorial jurisdiction in criminal cases-a serious infringement upon China's sovereignty--and secured the nost-favored-nation treatment for Britain. This latter provision guaranteed that if the Chinese Enperor subsequently granted additional privileges or immunities to other forejgn countries, the same immunities and privileges would be extended to and enjoyed by British subjects. 10

When the American Government Iearned that Great Britain had wrung the most-favored-nation agreement from the overwhelmed Manchus, the United States felt that the time had come to give serious attention to the future of American trade and commerce in China. 11 It was to safeguard the future of this trade and comerce that President John Tyler authorized the intrepid diplomat Caleb Cushing to seek the most-favored-nation treatment for American

$$
\begin{aligned}
& \text { Ifbid., p. 124. 9 9 Ibid., p. 125. 10 10 } \\
& 11_{\text {Ibld. }} \text { p. } 129 .
\end{aligned}
$$


businessmen, 12

Cushing was eminently successful in carrying out the instructions of his superior. In 1844 , the United States concluded its first treaty with Peking. Both Congress and the American public gave hearty approval to the comnercial treaty which Cushing had concluded, for as one Congressman observed, no one knew "'just how much of our tobacco might be chewed [by the Chinese] in place of opium.'113 The most-favored-nation treatment for American merchants which Cushing had obtained in the Treaty of "anghia "expressed so exactly the real interests of Americans that it survived for a century."14 From this time forward, equal commercial opportunity in China was to be the cardinal principle of America's Far Fastern policy.15

In the strained atmosphere which existed in China after the Treaty of Nanking, the occasion for new war against the Manchus was not long in presenting itself. Purported insults to the Brttish Crown and the murder of a French Catholic priest were the "convenient pretexts for armed action."16 The ensuing conflict was brief and

12 John W. Miasland, "Commercial Influence Upon Far Eastern Policy, 1937-1941," The Pacific Historical Review, XI (September, 1942), p. 281 .

$$
13 \text { Clyde, p. 131. 14Ibid., p. } 129 .
$$

$15 \mathrm{~A}$. Whitney Griswold, The Far Eastern Policy of the United States (New York: Harcourt, Brace \& Co., 1938), p.6. ${ }^{16}$ Clyde, p. 152 . 
decisive. In the treaties of Tientsin (1858), the Chinese Government was compelled to accede to an expansion of the principles and practices set rorth in the treaties of 1842 and 1844 .

China was now fully opened to the inroads of foreign commerce. During the fifty years wich followed the treaty settlements at Tientsin, China was subjected to policies which reduced its soverelgnty to a fiction. 17 But at this moment, the eyes of America were not upon China. A civil war was about to break upon the badly divided American Republic. And when that war had come and passed, the United States was well on the way to becoming an industrial nation. Attention for the remainder of the nineteenth century would be turned inward upon self-development rather than upon the commercial prospects that lay beyond the broad Pacific. Although exports from the United States to China had increased rapidly during the fifteen years after the Treaty of Wanghia, rising from $2,276,000$ in 1845 to $8,906,000$ in 1860, the Civll War was to bring a change. The next thirty years or so were to see exports fall and a general languishing of the China trade. Absorption of productive capacity in the development of the American West was the primary reason for this decline. 18

\section{Harold S. Quigley, Far Eastern War, 1937-1941}

(Boston: World Peace Foundations, 1942), p. 32 .

${ }^{18}$ Charles S. Campbell, Jr., Special Business Interests and the Open Door Policy (New Haven: Yale University Press, 1951), p. 10. 
The outcome of this process of internal development was the transformation of the United States into a great industrial nation. By the end of the nineteenth century, America was already entering into that phase of mass production which was to give birth to a renowed interest in foreign markets. 19 Exports to China shared in the general expansion of foreign trade which had lain stagnant for the previous three decades. Between 1890 and 1900 , exports from the United States to China increased from $\$ 7,385,362$ to $23,745,000$. During this same period, however, America's total exports to all parts of the world rose from $857,502,548$ in 1890 to $1,478,050,000$ in 1900,20

Despite the fact that the China trade had recovered and risen to new heights in the decade prior to 1900 , the combined imports and exports of the United States with China amounted to only 2 per cent of total American foreign trade. The American industrial and financial community as a shole paid little attention to the Chinese market. Although some business groups expressed considerable interest in the potential of the China trade, the fundamental fact remained that "China was a remote and relatively insignificant province of American economic enterprise."21

Other forces were afoot, however, which were to

19Farley, Far Eastern Survey, V (July 29, 1936), 162. 20 Campbell, p. 10. $2 I_{\text {Griswold, p. } 24 .}$ 
support the speculations of those business interests which envisioned a bright future for American enterprise in China. As a result of the Spanish-American War, the nation became increasingly conscious of the Far East. 22 The United States emerged from the war as a power having important territorial interests in Asia.23 Those business circles in the United States which constantly stressed the value of the China market to America's continued prosperity combined with the small but vocal expansionist clique to press for the annexation of the Philippines. 24 Both the desire for the annexation of the Philippines and the desire for a more spirited defense of American rights and interests in China were comproducts of the expansionist impulse of the period. 25 Although this group was small, it can be credited with producing a climate of opinion favorable to the adoption of the Open Door Policy by the administration of President illiam Minley.26

The Doctrine of the Open Door

In the last two decades of the nineteenth century, China's humiliation had been made complete as the insatiable hunger of the Western powers for empire drove them to tear away areas over which China exercised suzerainty. In 1884, France seized Indochina. Two years

22 Campbeil, p. 41.

23Farley, Far Eastern Survey, V (July 29, 1936), 162.

24kasland, The Pacific Historical Review, XI (September, 1942), 82 .

25 Griswold, p. 26. 26Campbell, p. 1. 
later, Burma was absorbed into the British Limpire. Japan provoked a war in 1894 which ended with China's loss of Fornosa, its forced recognition of Korean "Independence," and, to make Feking's shame complete, the imposition of a large cash indemnity. Whenever China resisted, it was dealt with the nore harshly, compelled to sign more "treaties," "lease" more territory, and pay inore "indemnities. $" 27$

By 1897, the moment seemed very near when the Great Powers would begin the actual annexation of their respective "spheres of influence." The delicate balance of power among the Great Powers in China seemed on the verge of collapse, and in all probability the extinction of Chinese independence would follow. 28 China's quasi-colonial position resulted not only from the spheres which the powers had carved out over a fifty year period but also from the treaty rights that had been wrung from the declining Hanchus. Extraterritoriality was the most extensive of these privileges, but there were also tariff restrictions, and the rights of coastal and river navigation, of garrisoning troops, and of establishing a postal system. The United States had shared in this complex of prerogatives which so drastically Iinited China's freedom of action.29 But whereas the European states had carved

27Forman Harrison, Changing Chine (New York: Crown Publishing Co., 1948), p. 44 . 28 Campbe11, p. 25. 29Quigley, pp. 34-35. 
their Initials upon China by marking off special enclaves of influence, the United States had denied itself this typo of concession. 30

By 1898, then, all the salient features of the Far Eastern policy of the United States had virtually jelled. Equality of commercial opportunity, not territorial acquisition, was America's objective. Peace, amity, and trade formed the bed-rock of United States' policy toward China.31 But a half-century of gradual encroachments upon China's territories was apparently about to terminate in a flurry of land-grabbing which would spell an end to China's territorial integrity. These developments alarmed American merchants and missionaries alike, both groups fearing that they would be eliminated from the glorious future in China which both envisioned. Appeals were made to the State Department to intervene in the course of events. The British, who had a much vaster trade and financial stake in the Chinese Empire, added their exhortations to the clamor.32 Thus it was that Great Britain, which had considerable interests throughout all of Asia, and the United States, which had negligable interests but "gargantuan expectations," found reason to make common cause against

$$
\begin{aligned}
& { }^{30} \mathrm{Griswold}, \mathrm{p} .6 .31_{\text {Ibid., p. }} 8 . \\
& 32 \text { phomas A. Bailey, The Han in the street (New }
\end{aligned}
$$

York: The Macmilian Co., 1948), p. 286. 
further infringements upon China's tattered sovereignty.33 Secretary of State John Hay, working in close collaboration with the British, penned the first of the famous Open Door notes in 1899. In these notes, hay urged the powers to accept the ideal of commercial equality in China. Although most of the Great Powers accepted the principle of comercial equality only with extensive qualifications, Hay publicly announced that he had received replies from the powers which were "final and definitive." Then the Boxer Rebellion flared up in China only months later in 1900, Hay announced--this time without benefit of notes to the other powers--that the Open Door had been extended to include the territorial integrity of china, as well as equality of commercial opportunity within the Chinese Empire. "Thus, on the rushing tide of dramatic events, the new Open Door was floated bofore the public gaze. $n 34$

The popular notion persists that Hay's pen had effected the rescue of China at a time when its denouement appeared certain. Such was hardly the case, however. China was to a large degree the beneficiary of the growing rivalries among the Great Powers of turope. In their efforts to make certain that none gained any undue

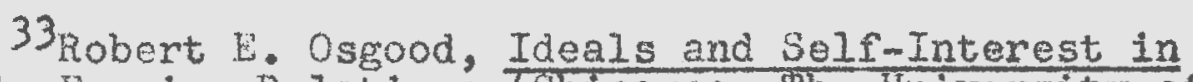
America's Foreign Relations Thicago: The University of Chicago Press, 1953), p. 61.

34Bailey, pp. 286-87. 
advantage, they effectively prevented each other from pursuing their territorial aspirations in China.35 The doctrine was no more effective than the power of Great Britain and the United States to back it up, and the United States did not have the armed strength to rescue Ching had Hay's bluff boen challenged. In point of fact, "neither Hay nor any other American official had any intention of enforeing it if called to book." 36

Furthermore, it should be noted that until 1900, Anerica's respect for China's territorial intescity was merely a self-imposed regulation. The United States was under no obligation to rush to China's defense if another power or combination of powers threatened to dismember it. As long as the United States pursued this policy, it was able to remain free of serious involvement in the political entanglements of Eastern Asia. But with Hay's pronouncement that the American policy of the Open Door now Included the territorial integrity of China, such a degree of detachment in the future would be virtually impossible. 37

The Open Door and Sino-American Economic Relations, 1900-1931 Threats to China's territorial integrity and America's commerce, however, were not to cease at the flourish of a pen. Theodore Roosevelt's first impulse

$$
\begin{aligned}
& 35_{\text {Ibld., p. } 287 .} 36_{\text {Osgood, }} .62 . \\
& 37_{\text {Griswold, p. } 7 .}
\end{aligned}
$$


during the Russo-Japanese War of 1904-1905 had been to favor Japan so that Russia's hold on Manchuria might be weakened and the Open Door thereby protected. 38 Pussia's efforts to restrict American commercial enterprise in Manchuria had been analyzed as but one expression of the czarist government's desire to dominate all North China. The treaty of peace itself, which had been concluded under the mediation of President Roosevelt, contained a provision binding Japan and Russia "not to obstruct any general measures common to all countries, which China may take for the development of the commerce and industry of Manchuria." 39 President illiam Howard Taft's policy of Dollar Diplomacy as it was made manifest in China was an aggressive but ill-conceived attempt to promote American capital by insisting upon the right of American interests to participate in a three-power consortium to build the Hukuang rallway. His efforts had been succeeded by the even more inept attempts by his Secretary of State, Philander $\mathrm{C}$. Knox, to interest several powers in a financial scheme to tear the Manchurian railways away from Russian and Japanese control.40 Both efforts proved unsuccessful, with the erstwhile enemies, Russia and Japan, cooperating to defeat

\section{$38_{\text {Osgood, p. } 67 .}$}

39T. A. Bisson, American Policy in the Far East, 1931-1940 (New York: Institute of Pacific Relations, 19401, p. 9.

$$
40 \text { Osgood, p. } 103 .
$$


this plan to internationalize the fanchurian railvay system. 41

During the first four years of woodrow wilson's administration, Taft's policy of Doller Diplonacy in China was discontinued.42 Wilson had insisted that the financial adventures in China wich the preceeding administration had championed be halted because of the stringent controls it involved over the Chinese Administration."43 In 1917, however, Hilson departed sharply from his policy of aloofness to international financial projects in China. Secretary of State Robert Lansing gave notice to American bankers and foreign governments that the United States was interested in joining in the creation of a new consortium based upon 2 broader membership and upon conditions that would not deprem ciate China's sovereignty. This abrupt shift in attitude grew out of new apprehension for the Open Door which had been engendered by the Chinese Government's reckless borrowing from Japanese banks. The Chinese Government, however, was not interested in the new consortium and the proposal came to nothing. 44

Both Taft and Milson had attempted to implement the pollcy of the Open Door by interjecting American influence in the form of private participation in large loans to the Chinese Government, and by encouraging direct investments

$$
\begin{aligned}
& \text { 4I Quigley, p. 37. } 42 \text { Bailey, p. } 240 . \\
& \text { 43 Quigley, p. 37. } \quad \text { 44Ibid., p. } 39 .
\end{aligned}
$$


by American businessmen. Both presidents had been thwarted in their efforts largely because of the apathy of American investors for such projects, an indifference which was based partly upon the knowledge of the extensive investments by other states already existing in China, and partly upon the tradition of "avoidance of forelgn entanglements." These obstacles placed the Department of State in the position of having to muster public opinion in support of this new departure intc world affairs.45 Fublic opinion, however, largely turned against Dollar Diplomacy.46 Investments in China remained small during this period, and the United States was forced to content itself with the more limited objective of merely acting as a brake upon the more aggressive powers. 47

Although few commercial groups in the United States believed in the viability of the China merket, the American Government did not fail to provide the necessary agencies and facilities for the promotion of Chinese-American commercial relations. Diplomatic officials concerned with Far Eastem affairs during the first several decades of the twentieth century were motivated by the basic assumption that China would one day be a great narket capable of

\footnotetext{
$45_{\text {Ibid. }}, \mathrm{p} .36$.

46 Samuel Flagg Bemis, The United States as a World Power: A Diplomatic History, 1900-1955 (New York: Henry Holt \& Co., 1955), p. 6I.$$
47 \text { Quigley, D. } 36 \text {. }
$$ 
absorbing vast amounts of American products.48 Government officials wrote pamphlets giving details on every phase of commerelal Iife in China, invariably pointing out the "vast opportunities for industrial development," outlining the facilities available to Americans resident in China, and even optimistically suggesting a criteria for the selection of the business representative in China. 49

The commercielized coastal region of China was the site of most of the markets for manufactured goods coming from the United States, 50 It was in this area that trade promotional organizations and activities were concentrated. A representative of the Department of Commerce was sent to the ancient capital city of Peking in 1914. American Chambers of Commerce were functioning vigorously at Shanghal, Tientsin, Hankow, and Peking by the early 1920 's. By 1925, American trade comissioners located in Shanghai and Canton were compliling a monthly resume of the China trade for general distribution among all Americans desiring such information, 51

48Masland, The Pecifle Historical Reviev, XI (September, 1942), 293 .

49See Juleen Arnold, China Trade Facts, U. S. Dept. of Commerce, Bureau of Foreign and Domestic Commerce (Washington: U. S. Government Printing Offlce, 1925).

50walter A. Radius, "United States Trade and the S1no-dapanese War," Far Eastern Survey, VII (January 5 , 1938), 2.

$$
51 \text { Arnold, p. } 12 \text {. }
$$


Offlcial encouragement, however, was not enough to stimulate greater American business activity on the China mainland. While total American investments abroad rose very rapldly after 1914--from $\$ 2,500,000,000$ to more than $\$ 16,000,000,000$ in 1930--1ess than $\$ 200,000,000$ (exclusive of missionary, medical, and educational enterprises) was invested in China. Only $\$ 40,000,000$ of this total was in the form of loans.52 In comparative terms, this means that of all the forelgn investments in China as of 1930, only 6.1 per cent were Anerican, 53 By contrast, British financial interests in China were six and one-half times as great as American holdings in 1931. Totaling nearly one billion dollars, British holdings constituted 39 per cent of all foreign business investments in Ghina. The Japanese were next with 37 per cent of the total, while Russian investments were a poor third with 11 per cent, 54

About four-fifths of all American investments in China were in business concerns: banks, public utilities, shipping, tobacco companies, oll stations, newspapers, and small factorles. These direct business investments by private American concerns totaled approximately $\$ 160,000,000$ or about 80 per cent of all American commercial interests

$52_{\text {Quigley, p. } 40 .}$

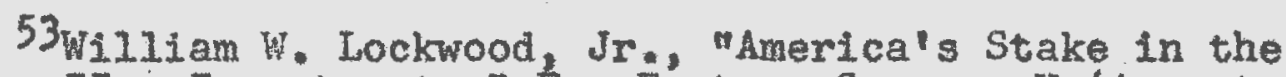
Far East, II: Investments," Far Eastern Survey, V (August $12,1936), 18.18$.

$$
54 \text { Quigley, p. } 41 \text {. }
$$


in China.55 The remaining 20 per cent, or about $40,000,000$, was in portfolio investments. This same ratio of direct to portfolio investments held true for all foreign investors In China in 1930.56

On the eve of Japan's invasion of Manchuria in 1931, American concerns made two major investments in China. Both investments vere located in Shanghai, long the focal point of American comercial activity in China. In 1929, two large American utility companies acouired a controlling interest in the Shanghai Power Company under terms which gave the company a monopoly in supplying electric power to the International Settlement at Shanghai. One year later, the American-owned International Telephone and Telegraph Corporation purchased the Shanghai Mutual Telephone Company, a transaction which gave the American concern a dominant interest in the telephone service supplied to the large foreign community in Shanghai. These two transactions substantially increased the American stake in the internationally controlled city. 57

The Rivalry of Japan and the

United States in East Asia Japan had emerged as the chief challenger of the

55 Quigley, p. 40.

56 $6_{\text {vei }}$ Ying-lin, China and Foreign Capital (Chungking, China: China Institute of Pacific Relations, 1945), p. 43. 178. 57Lockwood, Far Eastern Survey, V (August 12, 1936), 
Open Door in China from the early days of the twentieth century. At the outbreak of the Russo-Japanese har in 1904, President Theodore Roosevelt and the great mass of the Anerican people had favored the Japanese, who were regarded as a civilizing force at work in the Far East, and had opposed the Russians, who were looked upon as semibarbaric and a threat to American commercial interests situated in Manchuria. $58 \mathrm{Mr}$. Roosevelt soon realized, however, that the open Door policy had not been strengthened by the substitution of Japan for Russia in Manchuria. 59 From the standpoint of America's long-range interests in the Far East, Roosevelt grew as anxious to restrain Japan as he had been to check the adrances of the hussian bear 60 From this time on, relations between Japan and the United States steadily worsened. The Open Door policy became increasingly a barrier to Japanese advances on the Asian continent. 61

Jot only did Japan come to resent Araerica's position in China and the Far Fast as a whole, but it also became convinced that all forein investors in China were a potential threat to the continued economic prosperity of

$$
58 \text { osgood, p. } 67 \text {. }
$$

59 Samuel Flagg Bemis, American Foreion Policy and Diplomacy (New York: Henry Holt \& Co., 1959), p. 357. 60 osgood, p. 67 .

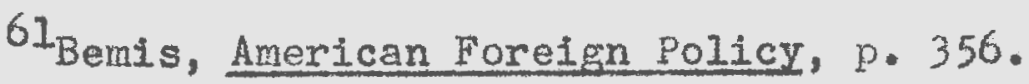


the Japanese Empire. As Japan had grown more industrialized during the last three decades of the nineteenth century and had adopted the techniques of mass production, it had become Increasingly pressed to find commodity outlets on the Asian mainland, 62 Japan had therefore come to regard the presence of other powers in China as inimical to its own vital intersists.

During World War I, Japan made its first serious challenge to the Open Door when it lodged the notorious Twentymone Demands againgt China. These exactions were so far-reaching in character that if the young Chinese Republic had boen compelled to accept them in toto, China would have become, a virtual Japanese protectorate.63 here again, how ever, the Open Door pollcy was used to block Japan's ambitious efforts to galn suzerainty over China. As soon as the content of the Twenty-One Demands was made public, Secretary of State William Jennings Bryan, in a note dispatched on March 13, 1915, Informed both China and Japan that the United States Covernment would not recognize any agreement or undertaking which would impair "the treaty rights of the United States and 1 tg citizens in China, the political or territorlal integrity of the Republic of China, or the international poliey relative to China

62 Charles A. Beard, American Foreign Policy in the Makirig, 1932-1940 (New Haven! rale University Press, 1946), p. 112 .

63 Benis, The United States as a World Power, p. 210. 
commonly. known as the Open Door policy."n64 The subsequent labors of American diplomacy, moreover, succeeded in persuading Japan to withdraw those demands which would have been fatal to Chinese sovereignty. Although the United States could not prevent China's acceptance of the remaining demands, the Amerlcan Government had once again blocked Japan's princlpal national objective! to gain mastery over China. 65 Desplte this setback on the Asian malniand, Japan emerged from the Firgt World War "with an equality in power and prestige" that could not be denied. Japan's new position of strength and the increasing rivalry between the United States and Japan in the Far East led shortly to the Washington Nava1 Conference of 1921-1922.66

The agreements reached at Washington in early Fobruary, 1922, ended the perlod of erisis in East Asia which had emerged as a by-product of the war in Europe.67 The three principal treaties which resulted from the conference represented an effort to strike a compromise between Japan and the Weatern powers. The Five Power Naval Treaty between the United States, Great Britaln, Japan, France, and Italy, declared a ten year "naval hollday" during which no new capital ships were to be bullt, and imposed a ratio

64Bisson, p. 12 .

65Bewis, The United States as a World Power, p. 210. 66 Bemis, Amertean Forelen Pollex, p. 456. 67Biason, p. 13. 
of 5-5-3-1.75-1.75, respectively, on capital ship tonnage.68 The terms of the Four Power Preaty constituted a multilateral pledge between the three great naval powers and France regarding the insular possesstons in the Pacific. The four states agreed to respect each other's rights in insular possessions in the Pecific region and to consult together if those rights became the subject of controvergy or should be threatened by an outside power. A third agreement, the Nine Power Treaty, embodied the most sweeplng affirmation of the American principle of the Open Door ever made. All the nation assembled at Washington agreed to respect the territoriel and administrative integrity of China, as well as equality of commercial opportunity within China. 69 The special treaty privileges which had been wrung from China in years past were not touched by this pact, however.

The Washington Conference allowed the United States to retreat from "active ilplomacy in the Far. East" by making the American policy of the Open Door the responsibility of all the powers which subscribed to the Nine Power Treaty. The United States was thus no longer the sole guardian of those principlea embodied within the Open Door. The naval limitations imposed by the Pive Power Treaty, moreover, made it impossible for the American Government to defend the Open Door.70 This condition,

680sgood, p. 339. 69 Ibid., p. 340.

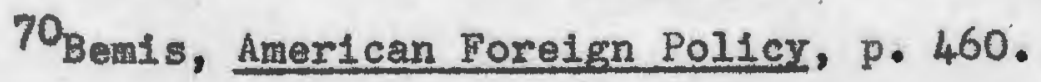


however, was not substantially different from that which had existed prior to the Conference; the United States had never been sufficiently powerful to sustain the Open Door. From the time of Hay's original announeenent of the Open Door polley no American statesman had ever contemplated Its enforcement: the Five Power Ireaty did not change this situation. $" 71$

America's frustrating intervention in the eplsode of the Twenty-One Demands in 1915, President Hilson's attempt to revive the four-power consortium in 1917, the disturbing presence of American troops in Siberia immediately following World War I, and the restrictions theoretically imposed upon Japan at the Washington Conference in 1922, persuaded the Japanese that they had found an antagonist in the United States.72 It was the diplomatic efforts of the United States, then, rather than the extent of American lnvestments, which ultimately convinced the Japanese that American polley was designed to frustrate their expansion in Chlna and throughout the Far East.73

710sgood, p. 341. 72 Ibid., p. 335.

$73_{\text {Quigley, }}$. 36. 
CHAPTER II

\section{AMERICAN COMMERCIAL INTERESTS IN CHINA, 1931-1937}

The Manchurian Crisis and United States Policy

On the night of September 18, 1931, Japan went on the rampage in Manchuria. The contest between the railitarists and the moderates which had been constant in twentieth certury Japan had turned once again--and for the last time-rto the favor of the expansionists.

In the decade before the thrust in Manchuria, the moderates had directed the fortunes of the Japanese Empire. The agreements made at Washington in 1922 had been a model of friendy conciliation" involving compromises by the government in Tokyo which no militaristic regime would have permitted. 1 To be surs, the years before 1931 had seen no retreat on the part of the Japanese from their determination to maintain the special position which they had achieved in Manchuria at such a cost in the Russo-Japanese War of 1904-1905. But Japanese foreign policy in the period before the Manchurian incident had been guided by men who had attempted to find a solution to the "wanchurian problem" by conciliatory means. The militarist clioue,

$I_{\text {Henry L. Stimson and NcGeorge Bundy, On Active }}$ Service In Peace and War (New York: Harper: Bros., 1947), 
however, had continually sought to replace the economic objectives of the moderates with a program of active imperialism. In the parlance of the extremists, they were determined to undertake a more "positive" course of action in hianchuria. $^{2}$

The grinding circumstances which resulted from a world-wide economic depression did much to discredit the moderates in the eyes of the Japanese people. Between 1929 and 1931 the foreign trade of Japan, vastly important to that maritime nation, was slashed in half. When other nations sought to export the depression by raising prohibitive tariff barriers against imports-a beggar-my-neighbor policy which the United States itself adopted--the Japanese economy felt the pinch. Under such conditions, Japanese opinion moved away from its former acceptance of a program based upon the peaceful pursuit of trade abroad.

The expansionists had been ready at hand with an alternative program of forceful imperialism which they presented in glowing terms to a people stricken by economic blight. ${ }^{3}$ With a finger on the pulse of the nation, the Japanese militarists had moved decisively in mid-September, 1931, Swiftly over-running the Manchurian provinces of China, and presenting in short order their people and the world with a fait accompli. The government in Tokyo, which at the last minute had learned of the plot and had attempted desperately to stop it, felt compelled to ratify

$$
\text { 2Ibid., p. 225. } 3 \text { Ibid. }
$$


the action "doubtless in the conviction that if it did not a revolt of the Army would ensue. 14

The offleial American response to Japan's assault upon Manchuria came on January 7, 1932 in a note which was delivered to both China and Japan. This caveat, which had been prepared by Secretary of State Henry L. Stimson at the direction of President Hoover, informed both parties that the United States would not recognize the legality of any de facto situation nor of any treaty or agreement which might impair "the treaty rights of the United States or its citizens in China, including those which relate to the sovereignty, the independence, or the territorial and administrative integrity of the Republic of China." 5

This was the Stimson doctrine of nonrecognition. Stinson himself, however, gave full credit to William Jennings Bryan for providing him with a precedent of nonrecognition in the Far East. When Japan had lodged 1ts notorious Twenty-One Demands against China in 1915, Bryan had notified both China and Japan that the United States would not recognize any agreement which violated American rights under the Open Door. 6

Secretary Stimson had wanted to halt the Japanese

4Joseph W. Ballantine; "Mukden to Pearl Harbor: The Forelgn Policies of Japan," Forelgn Affairs, XXVII (July, 1949), 652.

${ }^{5}$ Stimson, pp. 235-36.

${ }^{6}$ Cordell Hull, The Menoirs of Cordel1 Hull, I (New York: The Macmillan Co., 1948), 270. 
by taking more forceful measures against their imperialistic advances in Manchuria. But the American people were "in no mood to depart from the non-entanglement tradition."7 The Great Depression had given rise to a plethora of domestic problems which had turned a traditionally isolationist people even raore in upon themselves. Stinson himself wrote in November of 1931 that "the policy of imposing sanctions of force. . had been rejected by America in its rejection of the League of Nations. "18 the American people, Stimson wrote, had "deliberately chosen" to rely solely upon treaties which had achieved the sanction of "public opinion alone." 9

With this background of popular sentiment, the Stimson doctrine of nonrecognition achieved considerable porsular support in the United States. Aggressive measures which mitht have provoked war were neatly avoided and yet the moral position of the United States was secure. The policy had only one flaw: it did not stop the Japanese militarists "for as much as five minutes" in Manchuria or elsewhere.10 With each new report of Japanese advances in Fanchuria and with mounting evidence that the japanese foreign office was swinging in behind the militarists, it became increasingly clear that the forces of moderation within the Imperial Government had failed in their efforts

$$
\begin{aligned}
& \text { 7Bailey, p. } 249 .{ }^{8} \text { Stimson, p. } 244 . \\
& 9_{\text {Ibid. }} \text { 10 }
\end{aligned}
$$


to regain authority. 11

No matter what illusions the American people might entertain about the efficacy of nonrecognition, Stimson was aware of its severe limitations. The poljcy served as a purely moral weapon designed "less as a method of bringing the Japanese to reason than as a method of reasserting the American conviction that no good whatever could come from the breach of treaties." 12 The United States had spoken up in defense of international morality, but in terms of diplomacy it had hardly been very successful. By mid-January of 1932, Japan had achieved a complete military and diplonatic victory in Manchuria. The government in Tokyo had effectively resisted 211 attempts by other nations of the world to intervene in Japan's military penetration of the Asian mainland. 13

As for the threat which Japan's invasion of Manchuria might pose to American commercial interests 10cated there, Manchuria was not in 1931 nor indeed had it ever been a factor of much economic significance for the United States, either in terms of American trade as a whole, or in terms of imports or exports of any important commodities. 14 To Stimson's way of thinking, the fundamental factor at stake was American prestige in China and throughout the Far East, a factor of such Importance that it transcended in his mind any immediate damage which

$$
\begin{aligned}
& { }^{11} \text { Stimson, p. } 228 . \quad \text { I2 Ibid., p. } 234 . \\
& 13 \text { Ibid., p. } 239 . \\
& { }^{14} \text { Farley, Far Eastern Survey, V (July 29, 1936), 163. }
\end{aligned}
$$


might be done to American trade in Manchuria. It was his conviction that, in the final analysis, all of America's material interests in East Asia hinged upon retaining the prestige which the United States enjoyed "by virtue of its traditional support of China's territorial and administrative integrity."15 He belleved that if China's sovereignty and independence were allowed to be destroyed by Japanese aggression, the future of the United States in the Far East would be placed in serious jeopardy; a struggle between China and Japan might not only destroy the "potentially profitable" commercial relations between China and the United States, but might even constitute a danger to America's territorial possessions in that region. For Stimson, then, American policy could not be based upon any narrow apnraisal of what the American commercial community stood to lose by Japan's war in hanchuria. It was by insisting upon a close respect for international order and stability that American prestige and, consequently, America's material interests throughout East Asia could best be served.16

In formulating his policy, Stimson had been tightly encircled by the prevailing temperament of the American people. The doninant thought of the period surrounding the Hanchurian crisis was all for avoidance of Leagues and

$$
\text { 150sgood, p. } 353 \text {. 16 Ibid., p. } 354 \text {. }
$$


treaties or any agreement which implied commitments.17

Largely for this reason, it cannot be said that the American government, between 1921 and 1933, advanced very far toward the concept of collectire security. The dictun that America should retain its "freedom of action" thoroughly dominated United States policy. The climate of opinion ran strongly against taking part in any common action against an aggressor.18 Unable to defy such a powerful body of oplnion, Stimson had taken the only course he saw open to him: a grand-scale affirmation of the United States' traditional policy of the Open Door as expressed in the doctrine of nonrecognition. 19

The lines were now elearly drawn between the United States and Japan. On one side-stood the United States, persistont in its opposition to any action which would threaten the Chinese Republic's independence and territorial integrity. On the other stood Japan, irritated by the "flctions" of the Hine Power Treaty and unbending in 1ts determination to impose a solution singlemandedly upon the China problem. 20 After January, 1932, America's traditional sympathy for China and 1ts hatred of militarism and autocracy became increasingly important factors in the popular attitude toward Far Eastern policy. 21

17Dexter Perkins, "The Department of State and American Public Oplnion, The D1plomats, 1919-1939, d. Gordon A. Gralg, and Felix Gilbert fPrinceton: Princeton University Press, 1953), pp. 284-85.

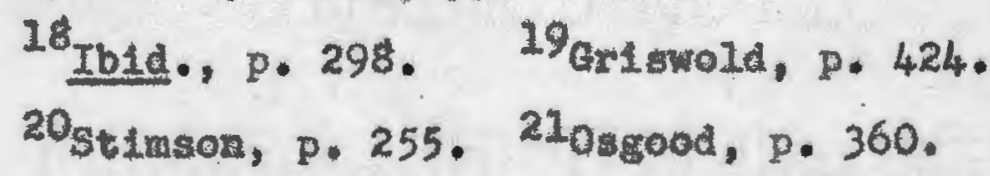


The moderate cabinet of Baron Shidehara fell from power on December 11, 1931. It had fought a losing battle to regain control over the military sinee the September attack had been launchod againgt Manchuria. Whth the last vestiges of opposition removed, the conquest of Manchuria was rapidly completed with the capture of Chinchow on January $2,1932.22$

The Open Door Closes In Hanchuria

It soon became clear that Japan's political and milltary control over Chinese territory was to be accompanied by the elimination of foreign business and industry from the conquered areas. Forelgn trado was restrieted to non-competitive commodities and those items most needed by the Japanes to assist them in consolidating the gains thus far made. 23 Durling the next several years, Japanese capltal investments in Manchuria greatly increased. By early 1935, Japan had achleved a virtual monopoly of investments in Manchuria. All other foreign interests, Including the small American one, steadily diminished in importance, 24 Foreign banking, trading, and construction concerns, finding themselves at a considerable disadvantage,

\section{Griawold, p. 421 .}

23w1111am C. Johnstone, The United States and Japan's Hew Order (New York: Oxford University Presa, 19411, p. 142.

24 John R. Stewart, "Foreign Investments in Manchur1a," Far Eastern Survey, IV (June 5, 1935), 81 . 
began to withdraw. 25

The Jpen Door for foreign investments in hianchuria had never, in fact, been held very wide. In the days prior to Japan's military conquest of the area in 1931, foreign trade and industry had been almost exclusively in the hands of either the Russians or the Japanese. 26 In 1930, Japan held 70 per cent of all foreign investments in Manchuria, valued at an estimated $8808,483,000$. Kussia's holdings constituted about 25 per cent of the whole, or approximately firit295,000,000. Al1 other foreign investments accounted for less than 4 per cent of the total. 27

American investments in lianchuria at this time were estimated at only $13,200,000$. These business interests were predominately of a commercial nature, including oil, tobacco, and match distribution, as well as banking facilities. The only Arerican commercial interest in Manchuria of any real importance, the profitable field of oil distribution, was eliminated by the kanchoukuo authorities in November, 1934, with the passage of an oil monopoly law. Under its provisions, the sale and distribution of oil was made a government monopoly. Foreign companies could continue to import petroleum products, but only if they agreed to sell exciusively to the Manchoukuo Oil Monopoly

25T. A. Bisson, "American Policy in the Far East," Foreign Policy Reports, XII (Februery 1, 1937), 274. ${ }^{26}$ Stewart, Far Eastern Survey, IV (June 5, 1935), 81. $27_{\text {Ibid., p. } 82 .}$ 
Bureau.28

The American Government made frequent protests against the application of this law on the grounds that it was a violation of the Open Door, a protest echoed by Great Britain and the Netherlands.29 Tokyo replied that, by refusing to recognize Manchoukuo, these powers had forfeited their claim to open door treatment in that area. 30 By mid-1935, the Manchoukuo 011 Honopoly had succeeded in forcing the Standard-Vacuum 011 Company, the Aslatic Petroleum Company, and the Texas 011 Company to close their offices in Manchuria, 31

New Threats to the Open Door, 1934-1936

In the apring of 1934, Japan made still another attack upon the doctrine of the Open Door. On Apri1 17, Eij1 Amau, a spokesman for the Japanese Foreign Office, released a statement to the press which boldly put forth Japan's claim to exclusive control in China.32 It acknowledged that Japan had a "opecial position and mission" in Eastern Asia. The note contended that Japan was compelled to act "ginglo-handedly" in order to maintain peace and order in East Asia, a responstbility which Japan shared

28 Ibid., p. 84.

177.

29 Lockwood, Far Eastern Survey, V (August 12, 1936), 30 Griswold, p. 442 .

31.B1sson, Forelgn Policy Reports, XII (February 1, 1937), 274.

32. A. Bisson, "Struggle of the Powers in China," Forelen Policy Reports, XII (Auguat 1, 1936), 122-23. 
with China alone. The Japanese Government would, therefore, oppose any attempt on the part of China to involve other powers in what was exclusively the duty of China and Japan.33

As for outside nations, the Amau statement warned them against undertaking any operations in china which might be prejudicial to Japanese interests, for under existing conditions even technical and financial assistance would acquire political significance. Supplying China with warplanes, constructing airdromes in China, sending military instructors or observers to China, or contracting loans to provide funds for political use would, the note concluded, tend to disturb the friendly relations between China, Japan, and other countries, and would ondanger the peace and order of Eastern Asia. Japan, therefore, would be opposed to such projects "as a matter of principle. $\$ 34$

The Amau statement was a direct challenge to British and American rights and interests in China. More specifically, the terms of the pronouncement called into question "a whole series of American economic and governmental relations with China." 35 One year earlier, the Chinese Government had arranged with the United States for a three-year, $\$ 50,000,000$ wheat and cotton credit to Nanking from the Reconstruction Finance Corporation. In

$$
33 \text { Ib1d., p. } 124 \text {. 34Ibid. } 35 \text { Ibid. }
$$


1930, the China National Aviation Corporation had been formed with 55 per cent of this airline owned by the Nationalist Government while the remaining 45 per cent was held by Pan-American Airways. Toward the end of 1933, the Central Aircraft and lanufacturing Company had been organized in China, with the Curtiss-Wright Corporation owning 64 per cent of this aircraft manufacturing plant, and the Douglas Aircraft Company controlling another 16 per cent.36 By 1936, this concern would be turning out sixty military aircraf't a year for the Nanking Government.37 During 1932 and 1933, moreover, the Aeronautics Trade Division of the Commerce Department had cooperated with these American aircraft corporations in the selection of a number of American aviation officers who assisted in establishing training schools for Chinese pilots. 38 During this same period, the sale of American aircraft and accessories, including military planes, had greatly expanded, rising from 207,000 in 1932 to $2,359,000$ in 1933.39

The Amau statement received world publicity. Its claim to Japanese preeminence in East Asta could not be allowed to pass unanswered. Within ten days, Secretary of State Cordell Hull had fornulated Washington's officlal

178.

36 Lockwood, Far Eastern Survey, V (August 12, 1936), 123. 37Bisson, Foreign Policy Reports, XII (August, 1936), 1936), 275.

${ }^{38}$ Bisson, Foreign Policy Reports, XII (February 1 ,

391isson, Foreign Policy Reports, XII (August 1, $1936), 123$. 
response. On April 28, 1934, Ambassador Joseph C. Grew, the ranking American official in Tokyo, delivered HuIl's reply to the Japanese Foreign office. In this note, Hull called attention to the fact that the United States, by virtue of existing treaties, "had certain rights and obligations" In China and was associated with China, Japan, and other nations in certain multilateral treaties relating to the Far East. 40 No nation, Hull reminded Japan, could, without the consent of the other states concerned, "rightfully andeavor to make conclusive its will in situations where there are involved the rights, the obligations, and the legitimate interests of other sovereign states. $1 " 41$

To this communication, the Japanese Government made no official response, and the matter was allowed to rest. fiull had reaffimed American allegiance to the same principles and treaty rights which Stimson had sought to uphold at the time of the ianchurian incident in 1931. The United States Government had again refused to recognize Japan's right to disregard them. 42 The Amau statement, for all its boldness, did not succeed in curtailing American relations with China.

On December 19, 1934, Japan gave notice that it intended to end participation in the naval limitations

$$
\begin{aligned}
& 4 \mathrm{OHull}_{\mathrm{Hu}} \text { I, } 279 .
\end{aligned}
$$

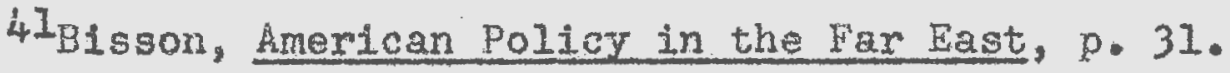

$$
\begin{aligned}
& 42 \text { Griswold, p. } 444 \text {. }
\end{aligned}
$$


treaties of 1921-1922. Those entrusted with the formulation of American policy in the Far Bast were once again at the crossroads of decision. As Secretary Hull saw it, there were two possible courses of action which the United States might follow. One was to withdraw gradually, "perhaps with dignity," from the Far Sast. This would mean, Hull believed, acouiescence in the nullification of American treaty rights, the closing of the Open Door, the abandonment of China to the acquisitive designs of Japan, relinquishment of the right to protect American nationals in China, and the surrendering of American commercial rights on the Asian mainland. It would, in effect, turn over the entire Pacific area west of Hawaii to the domination of Japan. 43 The other course of action was to continue to insist on the maintenance of law, the faithful observance of China's territorial and administrative integrity, and upon the rights and interests of Americans in the Far East. To pursue the latter course meant "a firm, though not aggressive," policy toward Japan. 44

As a nation attempting to uphold the doctrine of world order under law, both Hull and President Roosevelt felt that they could do no other than choose the second course. The most immediate reason for this decision to continue Arerica's traditional policy in East Asia was the deep-seated concern for the security of Anerican territorial

$$
\text { 43Hull, I, 290. } \quad 44 \text { Ibid., p. } 291 .
$$


possessions in the western Pacific. The Philippine Islands, long recognized as the United States" "Achilles heel" in the Far East, was still very much Japan's hostage. 45

During the next several years after the conquest of Manchuria, a new phase of Japanese economic and political penetration opened in North China. The technique of mass smuggling was employed in a conscious effort to undermine both Chinese and Western interests in that region. These smuggling operations seriously affected the position of all the Western powers in their trade relations with China. In 1935, it was estimated by the Bank of China that illegal entry of Japanese goods reached a total value of about \$53,000,000. If Japan's legal exports to China in 1935 are added to this figure, the total value of Japanese goods sold to China for that year can be placed at over $100,000,000$. By contrast, United States exports declined from $69,000,000$ in 1934 to $38,000,000$ in 1935.46 Both the United States and Great Britain protested against Japan's efforts "to bring about a substantial change in the political status and condtions in several of China's noxthorr provinces. $\$ 47$ Such protests, however, were completely ineffective.

\footnotetext{
45 Griswold, pp. 449-50. 1936), 131. 46 Bisson, Foreign Policy Reports, XII (August I, 47 Ibid., p. 129.
} 


\section{Sino-American Economic Relations}

on the Eve of War

On the eve of Japan's military assault upon China proper, American investments in China were estimated at a maximum of $\$ 200,000,000$. These investments remained predominately business holdings in properties owned and operated by American nationals. Nothing had happened to make Chinese corporations more attractive to imerican capital. Similarly, American investments in Chinese Government obligations continued to be small and not very successful. In 1936, the only American issue of Chinese Government securities was the one-fourth share of the Hukuang Railway bonds of 1911 . It w1l be recalled that the participation of American bankers in this project was secured only after President Taft made a dramatic appeal to the Chinese Regent requesting thet American capital be allowed equal participation with British, French, and German funds. Of the original $\propto_{1}, 500,000$ alloted to the United States, [1,402,000 were sti11 outstanding in 1936, with interest payments in arrears by $£ 402,810.48$ The direct return enjoyed by Americans from such investments remained a "negIigible item" even in the Great Depression year of 1935.49 By 1936, the predictions of a vast China trade were still to be realized. The growth which had occurred in the Far Eastern trade must be attributed, not to China, but primarily to other countries: the Philippines, British

${ }^{48}$ Lockwood, Far Eastern Survey, V (August 12, 1936), 
Malaya, the Netherlands Indies, and above all, Japan. In 1936, Japan accounted for no less than 43 per cent of all American trade with the Far East.50 In 1936, the value of American exports to Japan was $204,300,000$, while China accounted for only $\$ 55,400,000$ of America's exports. Of imports from the two countries, the United States received from Japan commodities worth $\$ 171,000,000$. America's ageregate imports from China were valued at $882,800,000$. In brief, Japan was the United States' third best customer in 1936, while the United States was Japan's best customer. China ranked well below Japan in each capacity. 51

While the dollar value of America's trade with China had grown through the years, its relative importance revealed iittle change: from 2.7 per cent of imports and 2.3 per cent of exports in 1901-1905, to 3.2 per cent of imports and 3.7 per cent of exports in 1931-1935, with only minor fluctuations along the way. 52 Despite a policy of hostility to Japan from the first years of the twentieth century, American trade with Japan had doubled and sometimes tripled that with China.53

Among the items which loomed large in America's exports to the Far East during the mid-ithirties were cotton, tobacco, and petroleum products. Cotton represented more than one-third of the value of all American

50Farley, Far Eastern Survey, v (July 29, 1936), 163. $5 I_{\text {Griswold, p. } 468 .}$

52Farley, Far Eastern Survey, V (July 29, 1936), 163. ${ }^{53}$ Griswold, p. 468 . 
exports to East Asia. Constituting more than half of all exports to Japan, the cotton trade was of the most vital concern to the Southern states. China's share of this trade, never large, declined during the early 'thirties, while that of Japan increased. 54

More than half of the United States' flue-cured tobacco was exported in the 1928 -1929 season, and more than one-third of this amount was exported to the Far Fast, mainly to China and Japan. The growth of the Chinese cigarette industry caused exports to fall off drastically in 1935. It was chiefly the decline of the Chinese market which was responsible for the fact that exports of fluecured tobacco to East Asia represented only about 7 per cent of domestic production in 1934-1935, as compared with 19 per cent in 1928-1929. A high tariff prevented Japan from being a large consumer of American leaf tobacco.55

The major industrial group with a considerable stake in the Far East in 1935 was the petroleum industry. Although oil was the most important non-agricultural item sold to Asia, exports to the Far East represented no more than about 2 per cent of domestic production of refined products. China took a large percentage of the United States' exports of kerosene while Japan's growing fuel requirements made her an increasingly important customer for crude petroleum, gasoline, gas oil, and fuel oil.56 $166-67$.

54Farley, Far Eastern Survey, V (July 29, 1936), 55 Ibid., p. 167. 
Throughout the early 'thirties, however, a fundamental change in the character of America's trade with China was perceptible. Throughout this period there was a growing trend on the part of China away from the importation of agricultural commodities and toward an increased demand for manufactured goods.57 This shift in emphasis resulted in part from technological advances in Chinese agriculture. By instituting a policy oi egricultural protectionism, China was able to limit importations of American cotton, wheat, wheat flour, and tobacco, and to replace them with domestic output. The four agricultural products which constituted the bulk of China's imports from the United States in 1932 had shrunk to less than 20 per cent of the total in 1935, and in 1936, to less than 15 per cent of all. imports from America. 58

While Chinese importations of Arnerican goods diminished between 1932 and 1935, Chinese exports to the United States steadily increased from 1932 to 1937. This increase was largely the result of the United States' growing participation in the export trade of Szechwan Province. In 1936, about one-third of American imports from China consisted of wood oil and goat skins, both of which came primarily from this area of western China. 59

Vastly more important than the changes which took

57Kurt Bloch, "Chinese-American liconomic Relations and the War," Far Eastern Survey, VIII (January 19, 1939), p. 13.

$$
{ }^{58} \text { Ibid., p. 14. } \quad{ }^{59} \text { Ibid., p. } 15 .
$$


place in the Sino-American trade were the economic results of a silver purchase policy inaugurated by the United States Government in 1933. This policy restored "virtually unlimited marketability" to silver.60 In Nay of 1936, the Republic of China and the United States concluded an agreement which provided for the purchase by the United States of large amounts of silver from the Central Bank of China. In 1937 and again in 1938, the scope of the original arrangement was extended and broadened. 61 These agreements were to have the greatest political as well as economic significance. With the establishment of dollar exchange, the greatest obstacle to Chinese currency reform was removed. Under the provisions of the Silver Purchase Act of 1934, China was at last able to sell her previously unmarketable hoard of silver, thereby exchanging it for a war chest of liouid resources totaling more than $\$ 400,000,000$, a sum of importance both absolutely and in comparison to the resources available to Japan. 62

60 Ibid., pp. 15-16. 61 Johnstone, pp. 188-89. 1939), 17. 


\section{CHAPTUR III}

THE SINO-JAPANESE WAR, 1937-1938: THE CHALIENGE TO AMERICAN INTERESTS IN CIINA

$$
\text { Japan Invades China, } 1937
$$

On July 7, 1937, Japanese forces launched the second all-out attack upon China. The imnediate cause for this direct assault upon the mainland grew out of a minor incident near Peiping, provoked and enlarged upon by the Imperial Japanese forces stationed in the area. The Japanese army had once again chosen the time and the place for the attack, much as it had in Manchuria only six years before. This new aggression on the Astan continent, moreover, was a natural consequence of the rixed policy of expansionism upon which the army had been bent since 1928 . Unlike the tottering moderate government of Prime Minister Tanaka in 1932, however, the Japanese Government in 1937 made no real effort to limit the fighting. quite to the contrary, Prime Minister Konoye revealed to the Diet several weeks after the beginning of hostilities that the Japanese Government intended to mold a "new order" in East Asia. Thus, although the July aggression had been provoked by the Army, it was not now out of consonant with the goverment's avowed objective of reducing China to a state of 
vassalage. 1

Conditions existing in Japan had played a large part in the evolution of the expansionistic policy which had entered its second stage with the July 7 attack near Peiping. The home islands had been feeling the pressures of a burgeoning population. All usable land was already under cultivation. Anxious attempts were underway to expand both old and new industries, but capital resources were limited and raw materials from foreign lands were essential if progress was to be made in this cuarter. In spite of such serious limitations, the nation had been determined to have a military and naval force equal to those of the more affluent powers. In short, Japan's resources and her ambitions had been sadly out of balance. 2 Japan's already precarious position had been further jeopardized in the mid-'thirties by the impact of a catastrophic and world-wide depression. Wany foreign nations had raised import barriers as a measure to fight the internal effects of general economic collapse, making it increasingly more difficult for Japan to sell its products abroad. The nation still possessed ample gold reserves, but if this supply were to be drained off by a prolonged period of unfavorable balance of trade, Japan would be forced to drop back to a poorer standard of

IBallantine, Foreign Affairs, XXVII (July, 1949), 654.

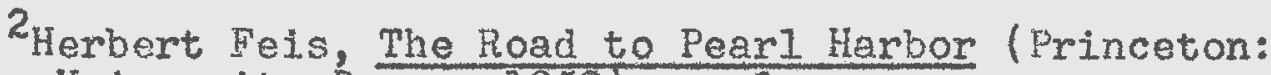
Princeton University Press, 1950), .3. 
living, and her stature as a nation among nations would inevitably diminish. Rather than face this unpleasant prospect, the Army and the "excitedly patriotic" had preferred another solution: the territorial extension of the Japanese Empire.3

Conditions abroad in 1937 made it seem not only possible but urgent for Japan to act decisively. In China, the spirit of nationalism was gaining nomentum, threatening not only Japan's activities in that country where more than 90 per cent of its foreign investments were located, 4 but also endangering Japan's control over Korea and Ianchoukuo. Many alarmed Japanese observers believed that if this surge of Chinese nationalism were to go unchecked, the result would be the ultimate expulsion of all Japanese interests from China. The opinion soon formed, especially in the army, that Japan must make its will felt quickly and forcefully on the China mainland. 5

An analysis of the situation in Europe seemed to offer further support for the bold course of action which the firebrands advocated. France and England, the two great foreign landholders in Asia, were held in balance by Germany and Italy. The United States, for its part, had so badly neglected its army and navy that it was incapable of

\footnotetext{
3 Ibid.

4"What's Our Stake in China," Business Vieek, August 7,1937, p. 15 . 5 Feis, p. 4 .
} 
undertaking a war in the western Pacific. In addition, the American people, deeply involved in domestic problens, would not, it was judged, go to war to rescue China or to protect European colonies. 6 The future for Japanese arms in China appeared bright indeed.

These expectations were realized to a large degree. In the last half of $193 \%$. Imperial armias penetrated deep into China. To consolidate their gains, the Japanese established puppet regimes through which iokyo could exercise control over the conquered territories. On December 14, 1937, the Peking Provisional Govermment was formed in Peking for operation in the five North China provinces under Japanese domination. Four months later, on March 28, 1938, the Reformed Government of Nanking was established under Japanese sponsorship to administer affeirs in the rexion of the lower Yangtze Valley. As principal cities were conquered, local systems of government were established, such as the Ta Tao or "Great Hay" Government in the area of Shanghai.7

Through these adninistrative agencies, Japanese authorities began to institute the "new order" which had as its objective the creation of a regional economy that would reduce Japan's dependence upon the outside world. In this scheme of things, the role of the Chinese nation was obvious: it was to be a market for the manufactured goods of Japan and a prinary source of the raw materials which

$$
\text { 6Ibid. } \quad 7 \text { Johnstone, p. } 142
$$


would make those same manufactures possible. Furthermore, cheap Chinese labor would be used to carry forward certain export industries, most particularly textiles, Japan's largest single export conmority. 8

\section{Japan's Policy of Commercial Exclusion \\ in China}

As soon as the Japanese had restored a degree of order in those areas under their occupation, measures were initiated by the puppet governments which were designed to ensure Japan's economic control over the subjugated araas.9 It was soon made abundantly clear thet the presence of other foreign interests was not compatible with Japan's economic objectives in China. The neasures instituted under the direction of Japanese officials were detrimental to all but Japanese commerce. Americans and members of other foreign commercial conmunities found themselves saddlod with travel and transportation restrictions, impeded by discriminatory regulations in the use of port facilities, hampered by censorship of corresnondence, cramped by import and export restrictions, and subjected to certain tariffs from which Japanese merchants were exempt.10 Foreign shippers were not permitted to use the railways without the

${ }^{8}$ Bisson, American Policy in the Far East, p. 96.
${ }^{9}$ Johnstone, p. 143 .
10 John R. Stewart, "The Var and Western Interests in North China," Far Eastern Survey, VII (October 12, 1938), p. 231. 
assistance--at a price--of Japanese forwarding companies. Closure of the lower and middle Yangtze River to all but Japanese shipping gave to Japanese companies a lucrative monopoly of passenger and freight service on the most traveled sections of the river.11 Vestern businessmen were often denied the right of access to their property and warehouses long after hostilities had ceased. 12 Such was the gamut the foreign commercial agent was forced to run if he wished to continue business operations in occupied China.

The establishment of a Japan-China-Manchoukuo economic bloc under the direction of the Japanese authorities was another instrument of discrimination used against the vestern businessman. In March, 1938, the Federal Reserve Bank of China was established on the basis of yen credits extended by the Yokohama Specie Bank. The new North China yuan currency which was subsequently issued was inconvertible into any foreign currency and was linked to the Japanese yen and the lianchoukuoan yuan in a tight yen bloc. The net result was the immobilization of a considerable amount of hestern trade and investments in North China, and the simultaneous stimulation of Japanese commerce. 13

$$
11_{\text {Quigley, p. } 129 .}
$$

12 David H. Popper, "Progress of the Sino-Japanese Conflict," Foreign Policy Reports, XIV (May 15, 1938), 60. $1938), 231$.

13Stewart, Far Eastern Survey, VII (October 12, 
The North China Development Company and the Central China Promotion Company, organized in May and June, respectively, of 1938, represented further attempts by Tokyo to force from the field all other foreign competition of any consequence. Both orgenizations were, in fact, agencies of the Japanese Government, established to monopolize every form of large-scale business enterprise. 14 These two large holding companies and their subsidiaries cornered the principal heavy industries and utilities in the areas under Japanese control. Through their operation, the Japanese pre-empted the whole field of industrial development in China for themselves. Economic control of occupied China soon rested alrost exclusively with Japan.15

One of the most drastic developments affecting not only foreign rights and interests but the very sovereignty of China arose from the purchase of Chinese real estate by Japanese nationals. Since the earliest days of China's contact with the Vest, alien landownership had been severely restricted. Even during the most aggressive days of Vestern economic imperialism, Chinese authorities had succeeded in limiting alien landownership to the immediate vicinity of the treaty ports and concessions.

Under Japanese military pressure, however, Chinese landowners were compelled to sell property indiscriminately.

$$
\begin{aligned}
& \text { 14Quigley, p. } 125 . \\
& 15_{\text {Stewart, Far Eastern Survey, VII (October 12, }} \\
& \text { 1938), } 234 \text {. }
\end{aligned}
$$


This new infringement--especially since cltizens of other countries were excluded from the same privilege-further buttressed the preferential economic position Japan was carving out for itself in China. 16

To the American businessman resident in China, the economic measures which were taken by Japan in those areas under its control seemed reminiscent of what had occurred after the creation of Manchoukuo in 1932. In the years which immediately followed the formation of that puppet state, Japanese monopolies, with the aid of Japanese capItal, had almost entirely eliminated American business north of the Great wall. It was obvious that the same methods were now being applied in China with the same disastrous results almost certain to overtake American commerce.17

Effects of the War on Sino-American Trade By August of 1937 the fighting had engulfed Shanghai, paralyzing China's most important seaport and industrial center, and the site of 65 per cent of all American business investments in China. 18 The Shanghai Power Company and the Shanghai Telephone Company alone were

${ }^{16}$ Kurt Bloch, "Alien Landownerghip Versus Open Door in China," Far Eastern Survey, VII (August 24, 1938), 198-99.

17 B1sson, American Policy in the Far East, p. 96. 18. C. Remer, Foreign Investments in China (New York: The Macmillan $60 ., 1933)$, P. 282. 
valued at over $40,000,000.19$ In the course of the fighting around the great international city, the property of the Shanghai Power Company escaped serious harm, but the Shanghai Telephone Company sustained damage in excess of several hundred thousand dollars. 20 While an accurate estimate of property damage was impossible, officials and businessmen placed the injury done to American holdings in the lower Yangtze Valley alone at $25,000,000.21$

Chinese-American trade relations were dealt a stunning blow by the hostilities of 1937-38. China's foreign trade had been in a flourishing condition in the years inmediately prior to the renewal of hostilities. In the first six months of 1937, with law and order extended over a larger area of China than at any time since 1911,22 the Chinese Republic had just begun to import considerable amounts of capital goods in the prospect of undertaking an extensive program of industrial development.23 The United States had shared in this increase in China's import and export trade. Yith much of America's industrial capacity gathering dust under the impact of a severe economic

19 rWhat's our Stake in China," Business Week, August 7, 1937, p. 14 .

20 Johnstone, p. 190.

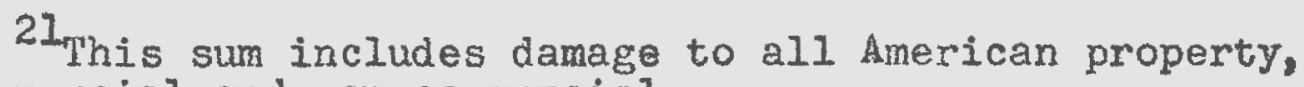
both commercial and non-commercial.

22 Johnstone, p. 165.

${ }^{23}$ Bisson, American Policy in the Far East, p. 95. 
depression, many optimistic heads had once again begun to dream of the vast benefits that could be reaped from a China undergoing modernization.

The resumption of tha Sino-Japanese conflict, however, had dashed this prospect. The announcement by the Japanese in late August, 1937, of a blockade along the Chinese coast, and the bombing of Chinc's limited internal communications network severely disrupted all foreign trade. As a result of the unfavorable conditions created by the war, the value of American exports to China dropped precipitously from $\$ 6,081,000$ in August, 1937, to H, 1559,000 in the following month of September, with only a slight recovery by the end of the year. 24 The first half of the year, however, had seen such vigorous trade relations between the two countries thet the total value of American exports to China in $1937($ 番49,697,000) exceeded that for $1936(46,819,000)$. Tracing trade returns from July of 1937 reveals a steady decline through the following twelve months of 1938. Again comparing figures on a yearly basis, American exports to China declined to $34,719,000$ in 1938, a drop of nearly $15,000,000$ from the provious year. 25

In terms of specific commodities, the great

24 paul B. Taylor, "America's Role in the Far Eastern Conflict," Forelgn Policy Reports, XIII (February 15,19381, p. 282 .

25 Johnstone, pp. 168-69. 
reduction in China's industrial activity after the beginm ning of hostilities was reflected in the sharp decrease in exports of American textiles, petroleum products, lumber, and iron and steel products to the Chinese Republic.26 The snall trader who dealt in these commodities was particularly injured by the resumption of the war in 1937.27 Only those who participated in exports of wer materials to independent China found the years 1937 and 1938 distinctly profitable. China's exports to the United States fell even more sharply, spiraling downward from a total of $\$ 103,616,000$ in 1937 to the considerably diminished sum of $44,189,000$ in 1938.28 The heaviest reductions were noted in inports from North China, an area of major Japanese military activity. Tung oil, the most important Chinese raw material purchased by the United States, could be supplied in 1938 to only about half the quantity and value of 1937.29

Reaction of the American Business Community to Japanese Aggression

The extensive dislocation which the Sino-Japanese war visited upon Chinese-American trade and the unmistakable efforts of Japanese authorities to force out all foreign commerce from those areas under its control did not fail to galvanize the American commercial community in

\footnotetext{
1939), 17.

27 Johnstone, p. 180. 28Ibid., pp. $168-69$. 29Bloch, Far Eastern Survey, VIII (January 19 , 1939), 17.
}

26 Bloch, Far Eastern Survey, VIII (January 19, 
China into action. Commercial groups entertained no notion of withdraing from China, as isolationist elements in the United States urged. Guite to the contrary, they were determined to maks every eifort to hold on, and they were persistent in their demands for the full protection of the United States Government.30 By the end of 1937, there was a far greater degree of unarimity of attitude among members of both business and non-business groups than at any previous time. 31

When hanchuria was overrun in 1931, American business agents in China had hesitated in their opposition to Japan. They had not envisioned Japanese ageression as a direct threat to their own rights and interests. By 1937, however, Japan's objectives had become clear, and American commercial groups were thoroughly alarmed by the orospect of Japanese hegemony over the whole of China. With Japan's military assault upon China proper, Americans in China almost without exception condemned Tokyo's policy of expansion and voiced support for the Nationalist Government. 32

Americans resident in China were quite concerned by the inaction and indecision which they believed to characterize Washington's official position with regard to the Far East. They roundly denounced the "professional

30 Masland, The Pacific Historical Review, XI (September, 1942), 293 .

$3 I_{\text {Johnstone, p. } 215 .}$

32 Masland, The Pacific Historical Review, XI (September, 1942), 295. 
pacifists" and the "Japanese protagonists" who were so anxious to "leave the field to the Japarese" that they called for the immediate withdrawal of all Americans from China. 33 The very fact that such outrageous demands enjoyed a wide audience in the United States--even anong certain "hysterical" officials in Washington-made it clear that the American people at home were "uninformed" and the Administration "confused." The American people in the United States, it was felt, would be brought to their senses only if Americans in China took the lead in indicating what should be done. 34

American business interests did not shrink from the task of making the United States public an informed public. The American business community in China was well organized and able to secure wide expression of its views in the United States. The American Chambers of Connerce were the most active organizations, sending frequent cables directly to the State Department, the White House, and to verious Congressional conmittees. The American Chamber of Commerce in Shanghai acted as a clearing house for its sister organizations in Tientsin, Hankow, and Canton.35 Indications of business opinion in China were usually well reported in the American press. The Shanghai and Tientsin Chambers of Commerce and the Shanghai American Junior Chamber of

33The China Weskly Review, September 11, 1937, p. 19. 34 The China leekly Review, October 2, 1937, p. 66. 35 Johnstone, p. 218 . 
Comerce regularly communicated their attitudes to the United States Chamber of Commerce. Vany of these communtques were, in turn, transmitted directly to government officials and to the press, 36

Shortly after the outbreak of hostilities in 1937 , businessmen and other residents of the American conmunity at Shanghai organized the American Association, a body established to coordinate the programs and activities of Americans in that city. 37 Its primary objective was to promote the safety of American life and property in Shanghai, and wherever else possible in China. $38^{\circ}$ This committee frequently protested to rashington against Japanese behavior, especially in cases where personal or property rights were violated.39

Working closely with the American Association was the American Information Committee, formed in October of 1938.40 The Information Committee often issued joint statements with the American Chamber of Commerce in Shanghai. Its most important work, hovover, was the publication of a series of booklets for distribution in the United States, by means of which it hoped to inform the American public of precisely what was happening in the rar East. 41 These pamphlets consistently expressed support for

36 Masland, The Pacific Historical Review, XI (September, 1942), 296.

37 Ibid. $\quad 38$ Johnstone, p. 219.

39Masland, The Pacific Historical Review, XI (September, 1942), 296.

40Ibid. 4IJohnstone, pp. 221-23. 
the Chinese and advocated a stronger United States policy toward Japan.

All these groups were bitterly aroused by the discriminatory commercial policies which the Japanese initiated in North China and the Yangtze vailey region during 1937-1938. They apjlauded the United States Government when it spoke firmly to Japan in defonse of American rights in China, and called for a stiffening of American policy when ashington appeared to vascilate. 42 But at all times a steady stream of intelligence flowed from china to the United States, informing the American public and the United States Government of Japan's latest efforts to eliminate all American commerce from China. 43

Reaction of the United States Government to Japanese Aggression

With the renewal of the conflict in China, the American Government was again faced with the thorny problem of determining what course of action the United States should follow in the Far East. There were three main, divergent lines of policy which could be pursued: (1) all possibijity of conflict with the belligerents could be avoided by declaring the Neutrality Act of 1937 to be in effect, accompanied by the withdrawal of American citizens

42"American Chamber at Tientsin Warns U. S. Businessmen," Export Trade and Shipper, XXXVIII (December 5. 1938), 8." $19381,230$.

43 Stewart, Far Eastern Survey, VII (October 12, 
and troops from danger zones; (2) the United States could participate in various collective measures designed to suppress war; (3) the United States could undertake the protection of American rights and interests abroad on a strictly unilateral basis.

The first possibility, although enjoying considerable support in the United States--and especially favored by the isolationist and peace blocs--did not find favor With the administration. If this purely isolationist course were followed, Japan might be encouraged to press forward the more rapidly, convinced that there was nothing to be feared from the United States.

While fervently desiring to discourage aggression, Nashington did not feel free to join in any collective action against the aggressor. The League of Nations, with which the United States had cooperated during the investigation of the Manchurian incident in 1932, was by 1937 a moribund organization that commanded no respect from lawless nations. Great Exitain and France, confronted with a rapidly rearming Germany and an obstreperous Italy, were deeply embroiled in the growing tensions of Europe. In the United Stetes itself, furthermore, the isolationist spirit was at flood tide, making American participation in any collective action against a foreign power virtually impossible. 44

Thus confronted with the dilemma of searching for 44Taylor, Foreign Policy Reports, XIII (February
15, 1938), $278-79$. 
effective ways of causing Japan to desist while staying uninvolved, 45 the Roosevelt Administration resorted to the traditional policy of insisting upon proper respect for American rights and interests in China. This was, in effect, a compromise policy between the complete abandonnent of American interests and activities on the China mainland, and active intervention to protect them.

On July 16, 1937, Secretary of State Hull issued a formal press release in which he repeated the principles which he had extolled since his entrance into office. He called upon all nations to faithfully observe international agreements and to uphold the principle of the sanctity of treaties. Without special reference to either China or Japan, he declared that the United States sought "effective equality of commercial opportunity," and urged upon all nations the "application of the principle of equality of treatment. 146

This was diplomacy by morality, a flickering candle in a naughty world. "In pure righteousness it outdid the Stimson policy of $1932 . " 47$ It expressed an attitude rather

$$
\begin{aligned}
& 45 \text { Feis, p. } 10 . \\
& 46 \mathrm{U} \text {. S. Department of State, Papers Relating to the }
\end{aligned}
$$
Foreign Relations of the United States: Japan, 1931-1941, I Thashington: United States Government Printing office, 1943) 326; (Cited hereafter as Foreign Relations: Japan, $1931-1941.1$

47Donald F. Drummond, The Passing of American Neutrality, 1937-1941 (Ann Arbor: The University of Vichigan Press, 1955T, p. 53. 
than a policy. Its severe limitations were all too apparent. But existing conditions, both foreign and domestic, regimented against any firmer expression of national policy at that time. If the United States could not move forward, at least it could decline to withdraw, and the reassertion of the Open Door and its attendent treaty rights seemed the one way in which the administration could offer resistance to Japanese expansionism in the Far East. 48 One of the foremost concerns of the United States Government after the resumption of hostilities was the presence of some 12,000 Americans in China. Fany of these persons were in areas wich were under attack. Both the President and his cabinet feared the repercussions which might result if American lives were lost. The outbreak of serious fighting around Shanghai in the fall of 1937 made the problem of adequate protection acute. 49

To safequard these Americans, washington acted with considerable dispatch. Diplomatic and consular officials were ordered to urge citizens of the United States to leave the danger zones as quickly as possible, and where possible to assist in this evacuation. To facilitate this process of removal, Secretary Hull asked Congress on August 17 , 1937 to appropriate $\$ 500,000$. At the same time, the Eovernm ment ordered that 1,200 marines located at San Diego be sent to Shanghai in order to give nore adequate protection to those Americans remaining in the area of those preparing

48 Ibid.

49 Taylor, Foreign Policy Reports, XIII (February $15,19381,283$. 
to depart.50 Infantry and marine detachments stationed at Peiping and Tientsin were kept on active duty, as were the nine river gunboats cruising in Chinese waters. 51 Admiral Yarnell, commander of the United States' Asiatic fleet, issued a statement in late September that the fleet would not be withdrawn and that it would accept any "necessary risk" to protect Americans who still remained in China. 52

During the first several months of hostilities when the United States Government was making every effort to protect American lives and property, President Roosevelt had purposely refrained from applying the Neutrality Act of 1937 to the war in China. 53 Under the provisions of this act, it was left a prerogative of the President to determine when a state of war existed between two countries. If he formally declared tht two or more powers were at war, a mandatory and impartial embargo upon loans and munitions exports to belligerents automatically became operative. The isolationist architects of the Neutrality Act had thus hoped to eliminate the possibility of some "incident" occurring which would draw the United States into a conflict for which it was not responsible. 54

The President's reasons for not calling the Neutrality Act into effect were twofold. First, by

50Foreign Relations: Japan, 1931-1941, I, 350.

$5 I_{\text {Griswold, p. } 461 .}$

52 Taylor, Foreign Policy Reports, XIII (February 15, $19381,284$.

53 Feis, p. 10.

54Taylor, Foreign Policy Reports, XIII (February 15, $1938), 280$. 
applying the act to the Sino-Japanese conflict, he saw that he would be helping Japan and hurting China. If American vessels were prevented from carrying materials of war to the two belligerents, no particular hardship would be worked upon the Japanese who had no shortage of weapons. The Chinese, however, would be left virtually defenseless. Second, if the American Government declared China and Japan to be at war-a condition which the governments of both countries had not acknowledged to exist--it might prove rerettable. "Names count; a war might be harder to end than an incident. "55

There was also the possibility that a neutrality proclamation might lead to a formal declaration of war between the two belligerent nations. If Japan then Invoked the rules of war and demanded the withdrawal of the armed forces of all third parties from China, the Americans resident there would be left without the slightest vestige of protection.56 Japan might go still one step farther and, under the privileges granted by international law in tine of war, challenge the right of the United States to trade with China. If American merchant vessels were stopped by Japanese warships and cargoes seized or destroyed, there would be no telling where recriminations might end.57 Despite the very real possibility that the United States might become involved in a foreign war as a direct result

55Feis, p. 10.

56 Taylor, Foreign Policy leports, XIII (February $15,19381,281$. $57_{\text {Hull, I, } 558 .}$ 
of imposing the Neutrality Act, American isolationists never tired of denouncing President Roosevelt for his failure to apply the measure.

As it was, the danger of interference with American shipping in the western Pacific almost forced the administration's hand on this issue. On August 25, 1937, the Japanese fleet proclaimed a blockade against Chinese shipping along the China coast. Foreign merchantmen were not mentioned. The following day, however, Japanese naval authorities declared that foreign vessels might be boarded for purposes of proper identification. Furthermore, the Japanese Government reserved the right to confiscate vessels carrying cargoes that in time of war would be considered contraband. 58 only a few days later, the accidental bombing of the U.S.S. President Hoover by a Chinese flier led Admiral Yarnell to warn American merchant ships to make no further calls at Shanghai. Such a rapid succession of incidents were fresh tinder for the advocates of an immediate declaration of the United States' neutrality. 59

These events in Asian waters occurred at the very moment when isolationist groups in the United States were focusing the public attention upon the sailing of the Illchita, a government-owned vessel carrying a cargo of nineteen planes destined for the Chinese Government. 60 With an eye toward recent happenings in the Far East,

58 Taylor, Foreign Policy Reports, XIII (February $15,1938), 280$.

59 Ibid., p. 284 .

60 Bisson, American Policy in the Far East, p. 61. 
Secretary of State Hull announced on August 27 that the United States Government reserved all rights on its behalf and on behalf of its nationals for damages to or loss of American lives or property sustained as a result of Japanese military activities. 61 Four days later cane the Japanese reply. The Minister of Foreign Affairs, Koko Hirota, informed Washington that the government of Japan was not liable for damages or iusses suffered by nationals of third parties as a result of the fighting in China. 62 with this announcement, neutralists brought even greater pressure to bear upon the administration in an effort to force the Neutrality Act into effect. 63

On September 14, 1937, Secretary hull instructed Ambassador Joseph Grew to inform the authorities in Tokyo that the United States Government could not accept the contention of the Japanese Government that it was not to be held responsible for damages sustained by nationals of third parties. The United States would continue to look to Japan for compensation whenever damage or loss was experienced by Americans in China. 64 on that same day, however, the Fresident announced that merchant vessels owned by the United States Government were no longer permitted to carry

61 Foreign Relations: Japan, 1931-1941, I, 490. 62 Ibid., p. 492.

63 The planes aboard the lichita were subsequently ordered unloaded at San Diego, California. They finally found their way to China via Europe.

64Forelgn Relations: Japan, 1931-1941, I, 497. 
any sort of war materials to elther Japan or China. Any private American vessel carrying articles of war to either belligerent would henceforth proceed at its own risk.65

Since American shippers could engage in carrying war materials to Japan at virtually no risk, the President's declaration did not bear equally upon both warring powers. But by partially invoking one provision of the Neutrality Act, Roosevelt was able to take the edge off the sharp protests thet had been coming from the isolationist camp throughout August and most of September, 1937. The demands to invoke the neutrality statute were never again as strong as they had been in those first two months of the undeclared Sino-Japanese war. 66

President Roosevelt had successfully withstood the interse pressure which the isolationists had thus far brought to bear upon him. He had persistently refused to abandon American citizens and their interests in China to the tender mercies of the Japanese. But the office of the chief executive is such that he must always seem to follow public opinion, or at least not go too far out in front of it. On October 5, 1937, however, Roosevelt violated this unwritten law in his memorable Guarantine Speech at Chicago, the isolationist capital of America. It evoked such an uproar from the noninterventionist camp that the administration was forced to make a hasty retreat. 67

65 Bisson, American Policy in the Far liast, p. 62. 66 Ibid. $67_{\text {Bailey, p. } 4 .}$ 
The President's quarantine Speech was a powerful address which contained the strongest threat of coercive action against Japan that had thus far been made by the United States. 68 In his address, Roosevelt referred to war as a "contagion" and observed that a "quarantine" was the community's usual method of checking an epidemic. He spoke of the need for "positive efforts" to preserve the peace of the world. 69 His suggestion that those nations infected with the epidemic of international lawlessness should be put in quarantine smacked sharply of some sort of embargo, and its timing hinted that the President had Japan in mind. This was followed the next day by a press release from the Department of State wich concurred with the League's decision that Japan had violated both the Nine-Power Treaty and the Kellogg-Briand Pact by its unwarranted attack upon China. 70

The President's forceful attitude at Chicago came as a surprise to the American public. His harsh tone created alarm among a large segment of his fellow countrymen, and most Americans rejected his "quarantine" suggestion. The proposal had come too abruptly; it was too radical a departure from the President's past comments on foreign affairs. A few groups rushed to his support, but the rest of the nation and most of the members of Congress were opposed. Psychologically, the country was not

\footnotetext{
68Taylor, Foreign Policy Reports, XIII (February 15, 1938), 280. 69Quigiey, p. 212. 
prepared for such a statement and was unwilling for the United States to adopt a more vigorous role in international politics. Americans were still convinced that the "epidemic" could not reach them. "They preferred to isolate themselves, rather than join in an uncertain effort to wipe out the disease." 71

President Roosevelt immediately realized that he had gone too far, too fast. At a press conference held on the day following his Chicago speech, the President refused to amplify his remarks of the previous day, frustrating the best efforts of newsmen to draw him out on the subject. then the Japanese Ambassador, Hirosi Saito, asked Secretary Hull on October 7 whether the United States Government had anything specific in mind, Hull stated that no action was contemplated for the time being. 72

This admission by the American Secretary of State, followed shortly by assurances from Great Britain that no disciplinary action against Japan was being contemplated in that quarter, prompted the Japanese to give notice that they would not attend the Nine-Power Conference which had been summoned to meet at Brussels on October 30, 1937. The announced purpose of this meeting was to find a peaceful solution of the crisis in China. France and Great Britain, preoccupied with worsening conditions in Europe, had informed the United States in advance that Washington would have to take the lead in effecting any such "quarantines"

$$
7 I_{\text {Feis, }} \text {. 12. } \quad 72 \text { Drummond, p. } 62 \text {. }
$$


in the Far East as the President envisioned.73 The obvious unreadiness of the American public for coercive steps on the one hand and tine government's unwillingness to reward Japan's aggression in China on the other completely hamstrung the American jelegation, 74

The conference, under these circumstances, proved futile. Japan, one of the parties to the dispute, was absent from the proceedings. France and Great Britain would not take the lead against Japan. The United States could not. It ended after three weeks with the democratic states reiterating their concern for the territorial integrity of China, but nothing was done to instill a similar sentiment in Japan. The total failure of the conference was underscored by Tokyo's defiant announcement that it would brook no interference by third parties with its policy in China. 75 On December 12, 1937, the most serious incident since the outbreak of the Sino-Japanese war occurred when Japanese aviators bombed and sank the United States gunboat Panay. The Panay had been escorting three Standard Oil Company tankers down the Yangtze River when the attack occurred sone twenty miles up-river from Nariking. The circumstances surrounding the attack suggested deliberate provocation, since the nationality of all the vessels was clearly designated by means of large ensigns and painted

$$
{ }^{73} \text { Griswold, pp. 459-60. }
$$

74 Taylor, Foreign Policy Reports, XIII (February $15,1938), 286$.

75 John Morton Blum, From the Morgenthau Diaries: Years of Crisis, 1928-1938, I (Boston: Houghton Miffin Co., 1959), P. 482 . 
flags. The survivors of the initial attack were machinegunned as they escaped from the sinking ships, and the Panay had been momentarily boarded by Japanese personnel from army motorboats. As a result of repeated air attack, three Americans were killed and many others wounded.76 In the United States, there was only a momentary outburst of Indignation, and demands for the withdrawal of a.1 Americans from China actually increased rather than diminished. 77 On Capitol Hill, Congressmen Impressed upon the public the necessity of remaining calm so that the forces of peaceful arbitration would have an opportunity to work out a quick and satisfactory settlement.78

The day following the bombing, Senator Willian $\mathrm{H}$. Smathers of New Jersey sent a lecter to Secretary Hull favoring the removal of all American citizens and vessels from the area affected by the conflict. In his reply of December 18, Hull reminded the Senator that for several generations, Americans had gone to China and had established themselves there in various occupations and activities. He pointed out that, along with other governments, the United States had accepted various rights and incurred various obligations. As filled with danger as the present situation might be, many Americans could not suddenly cut themselves off from the interests of a life-time, nor could the

$$
\begin{aligned}
& 76_{\text {Ibid. }} \text { I, } 485 . \quad 77 \text { Osgood, p. } 404 . \\
& 78_{\mathrm{U} .} \text { S. Congressional Record, 75th Cong., 2nd }
\end{aligned}
$$
Sess., 1937, LXXII, Part 2, 1968. 
American Government suddenly abandon its obligations and responsibilities. 79

This prosaic reiteration of the United States' moral duty to uphold international agreements gave no indication of the discord which had been produced among administrative officers by the Panay crisis. There had been considerable debate within Roosevelt's cabinet concerning the steps to be taken if diplomacy failed to solve the crisis. Both the President and the Secretary of State believed that the attack had been deliberate, simply another indication of Japan's desire to force all Westerners from China. 80 Vice-President Garner thought that only a show of force would have any effect upon the Japanese. Foosevelt, however, was confident that economic sanctions could bring Japan to terms without war. 81 Admiral William Leahy, Chief of Naval Operations, urged that the fleet be prepared for action at sea, a move supported by the President's adviser, Norman H. Davis, and by Assistant Secretary of State, R. Vialton fioore. The President and other members of his staff, however, resisted any such provocative action. 82 Secretary of the Treasury, Henry Morgenthau, consistently the advocate of more forceful measures against Japan, was

$$
\begin{aligned}
& 79_{\text {Hull, I, } 565 .} \\
& 80_{\text {Harold L. Ickes, The Secret Diary of Harold L. }}
\end{aligned}
$$
Ickes, Vol. II (New York: Simon \& Schuster, 1954), p. 275.

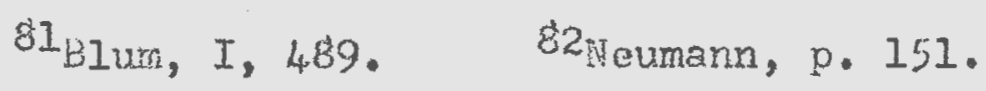


quite willing to go to war over the Panay issue. He stressed his apprehension that if Japan were allowed to continue unopposed, there would be no end to its advances in the Pacific. His assistant, wayne Taylor, replied that it would be "cockeyed" to risk war over such an issue. 83 Such was the degree of division within the administration. There was, hampily enough, no occasion for action. The Japanese Government hastened to make the nost effusive of apologies, promised to pay the indennities asked for by the United States, gave renewed assurances of respect for American rights and interests in China, and indicated that the military officers responsible for the wholly unauthorized attack would be punished. On December 23, the United States Government officially accepted the Japanese apology, and by Christmas Day, 1937, the matter was considered closed. 84

Apprehension among American officials continued even aftor the Panay incident had been satisfactorily resolved. The Japanese military, which had done much to provoke the war in China, had revealed a brazen disregard for American interests. The civil authorities in Tolyo, moreover, had failed to nake the militury adrit its part in the attack. The tinreats which this dangerous situation posed for the future were recognized by Ambassador Grew. On December 26, 1937, he wrote:

$$
839 \text { Ium, I, 487-88. } 84 \text { Ibid., p. } 492 .
$$


War between Japan and the United States will not come through mere interference or even destruction of our tangible interests in China, or yet from the breach of treaty rights, or the breaking down of principles for which we stand, but war may very easily come from some further act in derogation of American sovereignty. . . Therein lies the danger and it is a real danger which no one with knowledge of the irresponsibility of the Japanose military as distinguished from the Japanese Government can eliminate from the future picture. 85

The anomaly of undeclared though unlimited warfare provided a legal basis for diplomatic efforts by foreign governments to protect the lives and properties of their nationals within the war zones of China. 86 Great Britain, with its extensive economic investments in China, was keenly interested in promoting joint action among the Western powers in defense of treaty rights. The American Government, however, was not receptive to any suggestion of a multilateral undertaking anywhere in the world. The United States preferred to retain its ability to act independently and without reference to any foreign ally. 87

Japan was careful to do nothing which would diminish America's aversion for collective measures. Every effort was made to prevent the United States from becoming irritated to the point where it would seek to make cormon cause with Great Britain against the ambitions of Japan in East Asia. $88^{\circ}$ In the interest of preventing Anglo-American

85 Joseph C. Grew, Ten Years in Japan (New York: Simon \& Schuster, 1944), p. 240. 86 Quigley, p. 213. 87 Taylor, Foreign Policy Reports, XIII (February $15,1938), 284$. ${ }^{8} 6 \mathrm{Grew}, \mathrm{p} .244$. 
cooperation in the Far East, Japanese authorities in the occupied areas of China were consistently more solicitous of American than British rights. 89

A most striking manifestation of this element in Japanese diplomacy occurred at the tine of the Panay cxisis. Tokyo had rushed to meet the demands of the Department of State in an effort to settle the matter before popular antagonism could build up in the United States. At the conclusion of the crisis, the Japarese Minister of Foreign Affairs presented a note to American representatives in Tokyo outlining the steps that had been taken to prevent a recurrence of such an "accident." The note cited naval orders which had been issued instructing that the greatest caution be exercised in areas where American warships or other vessels were located, "even at the sacrifice of a strategic advantage." In addition, "rigid orders" had been issued to military, naval, and Foreign office authorities to give greater attention to the instructions which had been "repeatedly given" against interference with the rights and interests of the United States. Steps had already been taken, the Japanese Foreign Office concluded, to more fully ascertain the location of American nationals and thefr interests in China. 90

Throughout 1937 and 1938 , the western powers made $15,19381,285$.

90 Foreign Relations: Japan, 1931-194I, I, 550. 
only parallel representations against violations of treaty rights by the armed forces and adrinistrative agents of Imperial Japan. No real cooperative effort involving joint action by the sovernments of Great Britain, France, and the Inited States would occur until mid-1939.91

Throughout 1938, the Department of State dispatched a series of diplomatic notes to the authorities in Tokyo protesting against Japanese maltreatment of American citizens in China, the seizure of their properties, and the freezing out of American business by the establishment of Japanese monopolies.92 Joseph Grew, the American Ambassador to Japan, was the recipient of a constant flood of protests from Americans who had suffered injury as a result of the Sino-Japanese war. Such violations of American rights were the constant subject of his conversations with the Minister of F'orelgn Affairs. 93

In the last six months of 1938, the subject of American rights in China was discussed with increasing frequency by American and Japanese officials. The month of July was marked by the untiring efforts of Ambassador Grew to obtain Japan's respect for the diverse American interests which existed in China. On July 4, Grew passed nearly three hours in conference with the inister of foreign Affairs, exploring the entire field of American interests

91Bisson, American Folicy in the Far Bast, pp. $88-89$. 92.ulI, I, 569. 93Grew, p. 266. 
in China. The Japanese Sovernment assured the United states that hmerican treaty rights would not be curtailed. 44 In early October, Ambassacior Grew prescnted to the Jamanese Foreign office a bill of particulars which had been dram up at President Roosevelt'g request. In this statement, the President pointed out that despite repeated assurances by the Japanese Government, violations of American rights and interests in China had persisted. The United States now asked that the assurances so frequently given in the past be implemented. Specifically, the President requested that prompt and effective measures be taken to (1) end the discriminatory currency exchange control which had been imposed upon areas of China under Japan's control; (2) suspend any monopolistic practices which served to deprive American nationals of their legitimate share of the trade and industry in china; (3) discontinue interference by Japanese authorities with American property and other rights, including restrictions upon American trade and shipping. The acting hinister of Foreich Affairs, Frince Fumimaro Konoye, replied by once again riving full assurances that the Open Door in China would be "steadfastly maintäined." 95

On November 21, a long conversation occurred between the American Anbassador and the newly designated foreign Affairs linister, Hachiro Arita. Grew asked that immediate

94krew, pp. 251-52.

95 Foreign Relations: Japan, 1931-1941, I, 781-85. 
steps be taken to halt the air attacks which were destroying American conmercial and missionary properties, 10cated in areas often far removed from the scene of military operations. These unwarranted attacks were taking place constantly as "daily reports" pouring into the Embassy clearly showed. He rejected the Japanese explanation that these outrages were accidental because of the "volume and constancy of these depredations." He also asked that the lower stretches of the Yangtze River be made accessible to American trade and shipping, since Japanese merchantmen were openly engaged in commerce both up and down the river. The American Government urged that this discrimination be ended without further delay.96

With regard to the future of American comerce in China, Arbassador Grew asked the Foreign Minister if there was any element of truth in the allegation that American trade with China would, in areas under Japanese control, be tolerated only if conducted through Japanese middlemen. In response to this inquiry, Arita authorized the American Ambassador to give Secretary Hull a "categorical denial." Japan desired and intended to assure for itself certain raw materials, the Japanese Minister confided, but "there would be a very large and probably increasing field for American trade and other enterprise." 97

Such artifice and dissimulation, however, could no

96 Grew, p. 257.

97 Foreign Relations: Japan, 1931-1941, I, 807. 
longer conceal Japan's ambition to eliminate all foreign comperce from the China mainland. Only three days before Arita's conversation with Grev, the Japanese Government had announced that it intended to make the observance of the principle of equality of opportunity in China conditional upon the acceptance by the United States and the other powers of a "new order" in last A.sia.98

As 1938 drew to a close, Tokyo continued to give assurances concerning the future of the Open Door, but these assurances were Increasingiy surrounded by such qualifications as to rake them virtually meaningless, 99 on Necember 30, Ambassador Grew handed the Japanese Governinent the last diplomatic note of the year. In this message, Grew refterated the American Goverment's position that the principle of comercial opportunity in China was rot subject to nullification by unilateral action on the part of Japan. The United States, the message concluded, would not acknowledge or consent to any impairment of its treaty rights. 100

The Open Door, however, could not be held wide by mere words. The representations made by Anerican diplonats on behalf of American comercial interests in China did little more than amass clains against the Japanese Government. Grew believed that interference with Anerican treaty rights would end only when the Japanese were given

$$
\begin{aligned}
& 98_{\text {Ibid., p. } 800 .} 99 \text { Ibid., pp. 814-16. } \\
& 100_{\text {Ibid., pp. 820-26. }}
\end{aligned}
$$


reason to believe that the United States might do something more than talk.101 Subsequent events were to prove him right in this judgement. Only the frimmer days of 1939 and beyond lay ahead. 
CHAFTER IV

THE IMPACT OF AWERICAN COHLRCIAL IHTERESTS OH UNITED STATES FOLICY: AN ASSESSWINT

Commercial Interests in Relation to Bajor Political Factors

When Japan invaded the Asian mainland in 1937, Amexican businessmen in China insisted that the United States Government provide the fullest protection for themselves and for their investments. This demand was based squarely upon the guarantees embodied witinin the doctrine of the Open Door, an avowed policy of the United States Governnent since the first days of the twentieth century. With the promulgation of the Open Door in 1900, eouality of comercial opportunity within China and the territorial integrity of China had become official objectives of American policy in the far Gast. It was only logical, then, that American citizens with a finarcial stake in China expected their government to defend the principles of the Open Door in the face of Japariese imperialism.

The subsequent efforts of the United States Government to maintain the treaty riphts of its rationals in China must not, however, be taken as an indication of the success which the business commity enjoyed in its 
attempts to prod Washington toward a more spirited defense of American interests. Before the role wich American business interests played in formulating luited states policy can be accurately assessed, the factors which motivated the government's decision to uphold American treaty rights in China must be thoroughly explored. Such an investigation must begin with an analysis of the policies and attitudes which have been of significance in Sino-American relations. The Open Door Folicy as it found expression in China has always occupied a rather ambiguous position within the general franework of United States foreign policy. This ambiguity was matched by the ambivalence rather than consistency and singleness of purpose which has characterm ized American thought about the role of the United States in Asta. 1

The basic principles of kmerican foreign policy have been "few, simple, and enduring." In the public mind, the substance of United States policy abroad has been embodied in two fundamental concepts: nonentanglement and the Monroe Noctrine. From the days when the Pfonroe Doctrine was placed in effect to the eruption of world tar II, no two ideas have enjoyed such consistent support anong the American people. This firm adherence at the grass roots level of American society can largely be attributed to the fact that both policies were conceived of as being intimately assoclated with honeland security. ${ }^{2}$

$$
1_{\text {Neumann, p. 133. 2. }} \text { Balley, p. } 239 .
$$


Until 1900, the Open Door was in full consonance with the prevailing tone of United States foreign policy; equality of comercial opportunity everywere in the world was merely an expression of that basic fimerican notion of fnir play. At the time of the Boxer Revellion in China, however, Secretary of State John Hay had extended the open door to include, not only commercial equality within the Chinese Fmpire, but also respect for China's territorial integrity as vell. By this pronouncement, Hay placed the United States under obligation to prevent the dismemberment. of China by foreign powers. Preedom from serious involvement in the political entanglements of Lastern isia would henceforth be virtualiy impossible. 3

Ith the official promulgation of the Open Door Doctrine in 1900, the traditional American principle of noninvolvement in the affairs of distant lands had been violated. The United States had become the theoretical guardian of chinese sovereignty, an obligation far beyond American shores. It was, in fact, an obligation which the American Government apparently had no intention of fulfilling. If the United States had entertained any serious notion of enforcing commercial equality in China or of preserving China's territorial integrity in accordance with the provisions of the Open Door, it would need assistance. It would have to negotiate alliances, understandings, or other arrangements of mutual advantage wich would either 
supplement its own limited power or construct a trustworthy political substitute. Such provisions, however, were never forthcoming. Hidespread public indifference to matters beyond American shores precluded the possibility that any steps would be taken which would serve to bring national power into balance with this new turn in national pollcy. Having so abruptly acquired a political stake in the distant western Pacific, the American poople quickly exerted their privilege to ignore it. 4

The Open Door has from the beginnins, then, struck a rather hollow note in United States foreign policy. The Far Rast was too remote from the experience of most Americans to generate any active concern for American interests in China.5 United States officials, moreover, never exhibited any deep concern for the independence and integrity of China because they fully realized that their fellow countrymen would not fight to uphold the Open Door in an area half-way around the world from them. 6 inenever the Open Door was challenged, the Unfted States Government limited its response to the simple declaration that it would refuse to recognize any agreement or understanding which would impair the treaty rights of American citizens in China, or which would violate the administrative or territorial integrity of the Chinese nation.7 This

40sgood, p. 79. 5Neumann, p. 134.

6 Bemis, American Foreign Policy and Diplomacy, p 457. 7Bisson, American Foreign Policy in the Far East, p. 12 
technique had been employed by Secretary of State william Jennings Bryan at the time of the notorious l'wenty-One Demands in 1915. It was to be used again by Secretary of State Henry L, Stimson when Japanese armies overran Manchuria in 1931-1932.

Eeyond such diplowatic reproaches, however, the United States officials were never willing to go. At the time of the Washington Naval Conference (1921-1922), Secretary of State Charles Evans Hughes told the American delegation that the United States "would never go to war over any aggression on the part of Japan in China." Ten years later, Elihu koot, who had served as Secretary of State under Theodore Roosevelt (1905-1909), could still write that it had "never entered the head" of any American President or Secretary of State to send forces to China in defense of the Open Door. 8

In short, the Open Door was expendable. It had never expressed any vital interest of the American people or of their government. As an economic document concerned with comercial opportunity in a distant land, it represented a hope rather than a reality, an ideal rather than a polfcy. When threatened by the depredations of some foreign power or combination of powers, the United States had given verbal support to the dual principles of equality of commercial opportunity and the territorial integrity of 
China, but there had never been any question of using armed force in defense of the Open Door.

Then Japan indicated its contempt for the Open Door in 1931 and again in 1937, the United States Government attached no great importance to the maintenance of the treaty structure per se. American statesmen had beer faced with violations of the Open Door before and had never considered it important enough to warrant more than an official protest or a statement giving notice that no abridgement of existing treaty rights would be recognized. But Japan's military activities on the Asian continent might signal more than an infringement upon America's conmercial opportunities, something even beyond the violation of China's territorial integrity. Japan's assault upon China in 1937, following only five years after the aggression in Manchuria, was increasingly interpreted by American officials as but the beginning of a general imperialistic drive across the face of Asia. Such ambitions would ultimately endanger the security of America's Pacific possessions and disrupt the balance of power which the Washington Treaties had attempted to establish in East Asia.9

The concern of the United States Government thus transcended any immediate regard for elther China's territorial integrity or the commercial interests of Americans in China. With Japan threatening to dominate the whole of East Asia, it would have been impossibly narrow for 
American statesmen to gear the pollcy of the Unfted States to such limited objectives as the preservation of commercial equality in China or the administrative integrity of China, per se.

The primary objective of United States diplomacy from the time of the Manchurian incident throughout the remalnder of the decade was to offer some measure of resistance to Japan's imperialistic adventures in the western Pacific without at the same time embroiling the United States in war. Although minds were ransacked in a search for effective ways of causing Japan to desist while keeping the nation uninvolved, none could be found,10 Faced with this dilemma, the United States Governinent concluded that it could resist Japan only by insisting upon a strict observance of the internationally recognized principles contained within the doctrine of the Open Door. American officials were under no delusions concerning the grave limitations of such a purely moralistic policy, but under existing circumstances, it was the only means at the government's disposal.11 By defending the rights of American nationals in China, the United States hoped to sustain orderly processes in the sphere of international relations. 12 In its desire to hinder Japan's efforts at territorial acquisition, the American Government was often led to

10 Feis, p. 10.
$12_{\text {David H. Popper, "The Western Powers and the }}$
Sino-Japanese Conflict," Foreign Policy Reports, XIV
(August 1, 1938), 120.


display far more concern over China's eroding soverelgnty than it did interference with American economic privileges in China, 13

The Open Door, therefore, provided the United States with the means by wich $1 t$ hoped to deter Japanese expansionism on the Astan continent. If commercial interests were protected and sustained in the meantime, if China's administrative and territorial integrity were preserved along the way, so much the better; but the first objective of American statesmen was to offer some measure of resistence to the predatory instincts of Japan. This hierarchy of interests must be appreciated if the role played by American commercial interests in China during the critical years before World War II is to be properly understood.

When Japanese armies invaded China in 1937, the American Government had wanted to assist China in resiating Tokyo's efforts to extend the Empire. The powerful isolationist sentiment at home, however, had made any form of assistance, political or economic, virtually impossible. Stimon, in 1931, had found the American people in no mood to depart from the nonentanglement tradition; he had wanted to take forceful measures against the Japanese, but discovered that "the polley of lmposing sanctions by force.. - had been rejected by America in its rejection of the League of Nations, 114

\footnotetext{
13Taylor, Foreign Policy Reports, XIII (February 15, 1938), 278. U.gtimson, p. 244 .
} 
If this was true at the time of the Manchurian crisis, it was even more true when Japan launched its military offensive against China five years later. By the mid-ithirties, most Americans had firmly resolved never again to take part in the quarrels batween foreign countries. This determination to avoid foreizn entanglements found oloquent expression in the neutrality legislation of the years 1935-1937, passed in response to ovorwhelming public pressure. 15 The peak of isolationist strength was probably reached in early January, 1938, when the full force of administrative opposition was barely sufficient to defeat the much-debated Ludlow wer-referendum amendment, 16

Behind this grim determination to isolate America from the virus of foreign wars $3 a y$ the feeling of disillusionment which had swept over the country following the First World War. The nation had reacted strongly against the Wilsonian policy of extensive comitments in the world at large. Both the period of Immense prosperity which rolled across the nation during the 1920 's and the terrible economic depression which followed it served to concentrate American attention upon domestic rather than foreign matters. Those who conducted the foreign affairs of the United States during the interwar period, while often

15 William L. Langer and S. Everett Gleason, The Challence to Isolationism, 1937-1940 (New York: Harper \& Bros., 1952), p. 14.

16 Walter Millis, Arms and the State (New York: The Twentieth Century Fund, 1958), p. 17. 
far ahead of public opinion in the breadth of their vision and in their sense of the larger role which the nation ought to play, had to take account of this prevailing mood which had grasped the public mind. 17

Thus line came into being which American statesmen feared to cross. They could deplore the acts of international banditry which were taking place in the world around them. They could speak up in support of traditional national interests. But with the people of the United states so zealously desiring peace, no American offictal felt free to take any action that might possibly carry the nation toward or into war. 18 Perhaps the culminating expression of the utopian idealism which characterized the state of the public mind after World War I came about with the signing of the Pact of Paris in late August, 1928. This pact-which was celebrated across the length and breadth of the land-mad sought to end war by the fatuous device of making it illegal. 19

The renewal of the Sinomapanese conflict in 1937 had put the pacifist elements into full $\mathrm{cry}$. Isolationists in Congress and throughout the country demanded the evacuation of American civilians and American armed forces from China. 20 Senator $\mathrm{J}$. Hamilton Lewis of Illinois

17Perkins, pp. 284-85. 18keis, pp. 6-8.

19 Osgood, $\mathrm{pp} .346-47$.

20 Raymond L. Buell, Isolated America (New York:

Alfred A. Knopf, 1940), p. 107 . 
expressed a cormon feeling when he observed that

so long as the United States continues to maintain a regiment of soldiers [in Chine] the prospect of collision between those soldiers [and the Japanese] is very evident. . . The time has come when our Government should withdray that regiment from China and bring it home. . . 21

In the House of Representatives, Hamilton Fish, one of the leading isolationists, echoed this sentiment when he urged that "now is the tine . . to withdraw our armed forces, [our] gunboats, and to give up voluntarily our extraterritorial rights. $n 22$

The administration was forced to accede to this clamor for withdrawal to the extent of declaring that all Americans who chose to remain in China after repeated warnings to leave did so at their own risk. Moreover, on September 14, 1937, President Roosevelt announced that henceforth no government-owned vessel would be permitted to carry munitions to China or Japan and that any private vessels did so at their ow risk.23 on the whole, however, the government persisted in its policy of firm but cautious insistence of. American rights and interests in China. 24

Even the sinking of the American gunboat Panay by the Japanese on December 12, 1937, did not lead to any popular outcry for war. Instead there were even more

$$
\text { 21U. S., Congressional Record, 75th Cong., lst }
$$
Sess., 1937, LXXXI, Part 7, 8178.

$$
\begin{aligned}
& 22 \text { Ibid., p. 8157. } 23 \text { Buell, p. } 107 . \\
& 24 \text { Taylor, Foreign Yolicy Reports, XIII (February } \\
& \text { 15, 1938), 283. }
\end{aligned}
$$


caustic demands that the United States get 1 ts atiens and 1 ts naval craft out of the theater of war.25 One Congressman expressed this attitude quite encelntly when he remarked that "if the American gunboat Panay had been at home, it would not have been bombed, 26

The posibility that the United States might become Involved in a war with Japan over the destruetion of American comercial interest in China was repugnant to innumerable Congressmen. The fact that the gunboat Panay had been eseorting three Standard 011 veaselo at the thue of the attack did not escape notice. It was beyond contempt that "for a little trade and a few dollars in profits," American offielals wero willing to riak war.27 The protection of American commercial interests in China was not worth involving th1s nation of $130,000,000$ souls in a war they w11 be called upon to Plght and pay for."n26 Senator Robert R. Reynolds of Horth Carolina spoke for many of his colleagues when he resolved that "we are not going to follow the Ameriean dollar around the world to protect it." 29

25 Charles W. Smith, Public Oninion in a Democracy (Hew York: Prentice Hall, Inc., 1942), p. 518. 26. 3. Congresslonal Record, 75th Cong*, 3rd Sess., 1938, LXXXIII, part 9, 92.

27 Iold., p. 113.

28. S., Congressional Recond, 75th Cong., and Sess., 1937, LxxxtI, Part 3, 611.

290. S., Congressional Record, 75th Cong., 3rd Sess., 1938, LXXXIII, Part 1, 90. 
Efforts were renewed and intensified after the Panay Ineident to compel the Adminigtration to withdraw American natlonals, and the troops and shipe protecting then, from the war zones in China. There was a plethora of warnings that if the United States falled to get its marines and Its gunboats out of Chinese territory, further Incidents would surely occur. Ho one could guarantes that American gunboats would not be "blown up by the chinese in an effort to inclte us aginst the Japanese, or vice versa, 30 This rear was accompanied by the suspleion which some Congressmen entertained that "our Britigh brother across the seag" were "doing their best to Involve us over In China" so that the UnIted States would becone involved In protecting Great Britain's extensive investments in Aaia.31 The United States, it was cautioned, must not again becone the "cat's paw of Great Britain" in the far Bast as. it had been on the occasion of the officlal promulgation of the Open Door.32 For whatever variety of reasons, the vast majority of Congresamen, together with their fellow citizens, resched the same conelusion: Americans must be evacuated from China and for all those

30y. S, Congresslonal Record, 75th Cong., 3rd Sess, , 1938, LXXXIII, Part 1, 863.

31. , s., Congressional Record, 75th Cong,, 2nd Sess., 1937, LXXXII, Part 2, 1357.

32. S. Coneresational Recerd, 75th Cong., 3rd Sess., 1938, LXXXXIII, Part 3, 2477. 
who remain, official protection must be withdrawn.33

The administration, nonetheless, continued to uphold the treaty rights of American citizens in China in the face of a hostile public at home and an intemperate antagonist abroad. The Department of State, however, remained "acutely conscious" of the pressures from the American people for withdrawal of ali Americans from China, and could do little more than file officlal protests with the Japanese Government against a future reckoning. 34

The Open Door with 1 ts guarantee of equal, commerclal opportunity in China provided the United States Government with the only means by which it could hope to obstruct Japan's territorial ambltions. At the same time, however, there was the constant danger that some incident involving the lives and properties of Americans might occur which would draw the nation into war. This precariou situation was the source of considerable apprehension within the administration. American statesmen recognized with profound misgiving that to pursue an objective in forelgn policy, the United States Government was being compelled to sustain Insignificant financial interests under the most hazardous circumstances.

Had there not existed the larger objective of deterring Japan, there is ample reason to believe that the government would have been inclined to follow the

33Masland, The Pactfle Historled Rovior, XI (September, 1942); 283 .

34 BIua, I, 485 . 
suggestion that all Americans be removed from China-ma nation in which, after all, a full-scale war was being waged. The American Govermment had no intrinsic interest In the fortuns of buainess enterprizes operated by United States eitizens in China. The opposition within Rooseve1t's Gabinet to the notion of risking war to protect Sino-Amerian commerce was quite clear. It was strongly felt by several high administrative officials that the presence of a few Apericans with vested interests in China were subjecting the entire nation to an unreasonable degreo of rik. Yloe President Garner was of this opinion. He objected strenuoualy to the 1dea of risking war in the Far East for the sake of buslness, and he did not believe that contingents of Unfted States troops were justified in China.35 of I1ke mind was Secretary of the Interior Harold I. Ickes. Ickes ramarked that there was "no compulsion to invest maney in forelgn enterpriseg* and that those who did so could not expect the Ameritan Government "to sacrifice thousands of lives . . and millions of treasure in an attempt to protect their investments. 136

It seems clear, then, that the activities of the American comereial interests in China were not successful In working any transformation upon the sentiments of the American public or upon the course of Amertican policy toward Japan. The isolationist impulae among the people of the United States not only remained strong after Japan's

$$
\text { 35 Blum, p. 481. 36Iokes, p. } 209 .
$$


assault upon China, but actually intensified after the Panay Incident in December, 1937. Within high administrative circles in washington there was grave concern over the possibility that some incident might occur from which there could be no retriat because of the presence of vested American financial interests in China. Only on the broad grounds of curbing Japanese expansionism was the necessity granted of upholding the complex system of treaty rights which surrounded Americans and their properties in China.

Comercial Interests in Relation to Major Economic Factors

American trade and investments in China never approached the proportions which had been predicted at the beginning of the twentieth century. 37 The failure of American investments in China to grow cannot be attributed to the lack of official protection and encouragement on the part of United States Government officials. Rather it resulted in large part from the political and economic backwardness of Chine which made the nation unatractive to American capital. 38 Moreover, the American businessman was very skeptical of China's potentialities. As long as it remained impossible for the impoverished Chinese to absorb much in the way of imports from the United States, few commercial gromps foresaw the development of the Sino-American

37Masland, The Pacific Historical Review, XI (September, 1942), 282 .

38tockwood, Far Eastern Survey, V (August 12, 1936), 
trade.39

Commercial intercourse with Japan, however, had grown steadily over the years. At the turn of the century, Japan's trade with the United States already exceeded that with China. By 1920 the value of American sales to Japan was nearly five times that of sales to China. In contrast to the political and economic chaos which haunted China, the Japanese islands were the model of civil tranquility, and the adaptation of western industrial technology had transformed the old Hermit Kingdos into a modern nation. 40 American businessmen were usually well pleased with their contacts with Japan. The Japanese were prompt in meeting their financial obligations to American exporters and the goods Imported from Japan kept up to quality standards. A general feeling of good w111 and mutual respect had grown up between the commercial groups in both countries.41

By the mid-"thirties, Japan was of far greater economic importance to the United States than was China, 42 In 1936, China's share of America's forelgn trade was only 2.5 per cent, while Japan's was 7.7 per cent. At the same time, Anerican business investments in Japan $(\$ 218,000,000)$ were considerably more extensive than those in China

39Masland, The Pacific Historieal Review, XI (September, 1942), 293. 40 veumann, p. 136. 41 Masland, The Pacifle HIstortcal Revien, XI (Septenber, 1942), 293. 42 Parloy, Far Eastern Survey, V (July 29, 1936), 170. 
$(132,000,000) \cdot 43$ Sufrice it to say that among a large proportion of American exporting and importing firms doing business with all or several of the Fast Asian countries, Japan was both the best customer and the chief source of supply. Such was Japan's commanding role in America's economic relations with the Far East. 44

When the Sino-Japanese war erupted in 1937, the facts of the East Asian trade did not work to the advantage of the American commercial communty in China. In the first place, the economic stake of the United states in the whole of Asia was small. In the years immedi tely prior to 1937, exports from the United States to both China and Japan amounted to little more than 10 per cent of total American export trade, which in turn accounted for considerably less than 10 per cent of total American output. If commercial relations with either or both belligerents collapsed as a consequence of the hostilities, it was clear that no acute problem of economic instability would be created for the United States. 45 In the second place, Japan was more valuable to the commerce of the United States than was China. In 1936, American sales to Japan were in excess of $204,000,000$, while only $26,800,000$ in American commodities were marketed in China. 46 In terms of specific

\footnotetext{
43 Taylor, Foreign Policy Reports, XIII (February 15, 1938$), 278$.

44Masland, The Pacific Historical Review, XI September, 1942), $2 \frac{38-84}{4}$ 45 the Far East," Far Eastern Survey, VI (Sepember 15, 1937), 213. 46 Ibid.
} 
1tems, China's consumption of refined oil products in 1936 was only one-fourth that amount absorbed by Japan. 47 After 1935, moreover, the China trade in American cotton goods, the commodity that gave the United States its largeat trading stake in East Asta, had Virtually disappeared, whlle Japan had become the market for one-fourth of all the South's exported cotton. 48 Generously approximated, China represented slightly more than 1 per cent of the United States' forelgn trade. From any angle, China's place in the American economy was small, 49

Thus the economic realities of Asian-American commercial relations failed to give added weight to the demands of the American businessman in China for a more forceful United States polley agalnst Japan. "Not only was he robbed of the argument that h1s trade was an important link in America's econoric chain, but he was also confronted with other commerclal groups which considered trade with Japan of far greater importance to their own and to the nation's welfare. As might be expected, these groups were anxlous to maintain and expand their economic relations with Japan, and looked with disfavor upon any action

47Walter A, Radius, "The Play of Petroleum Forces in the Far East," Far Eastern Survey, VII (September 7, 1938), 208.

48W11liam W, Lockwood, Jr., North China and the United States Cotton Trade," Far Eastern Survey, VII (May $18,1938), 115$.

49 mhat's Our Stake in China?", Business Week, August $7,1937, \mathrm{p}, 15$. 
which might impair this trade.50 Already faced with a body of opinion in the United States which was hostile to the posstbillty of becoming involved in a foreign war "for a little trade and a few dollars," the American business community in China was confronted with a financial balance sheet that made one point inescapably clear: the China trade was of no vital importance to the United States. Aside from the insignificance of the China trade to the economy of the United States as a whole, American investments in China were marked by several special features which served to diminish the importance of Sino-American economic relations still further. The bulk of American holdings in China were the subsidiaries of large corporations located in the United States. The revenues which these companies derived from their business in China constituted only a small fraction of their total incomes. The petroleum industry, for example, the industrial group with the largest stake in the Far East, exported no more than about 2 per cent of domestic production in refined products to the whole of East Asta, 51 Similarly, the Shanghai Telephone Company, mentioned elsewhere as one of the most valuable American investments in China, supplied only about 3.9 per cent of the total operating revenues of International Telephone and Telegraph, the parent organ1zation. In brief, none of the larger American companies with investments in China was in a position to suffer more

50 vasland, The Pactific Historical Revien, XI (September, 1942); 285.

51 Farley, Far Eastern Survey, V (July 29, 1936), 167. 
than minor loss of income as a result of the Sino-Japanese conflict. In addition, property damage in almost every case was covered by ingurance. While distressed to see their China trade curtailed, the irmense size of these corporations allowed then to absorb this loss without any threat to their over-all financial position. 52

The outbreak of war in China was also the occasion for the American businessman to demonstrate the remarkable degree of resilience of which he has always been capable. The petroleu industry, gradually eliminated from the refining and marketing phases of the industry in Japanesedominated areas of China, quickly recovered by shifting its eaphasis to the fleld of crude oil which it sold in great quantitles to the Japanese. At the same time, American oil companies began to participate more extensively in the exploitation, development, and distribution of petroleum products in the Netherlands Indies, British Malaya, the Phllipplnes, and elsewhere. 53

The American tobacco industry, too, displayed this same realistic approach to the unfavorable conditions which war had brought to one of its best markets. Forced out of China by the disruptions which all wars bring to commerce, the industry announced that the "tremendous Chinese market" was ruined "for the duration of the war." The tobacco

52"Little Threat to U.S. Investments in China," The Financial World, LXVIII (September 1, 1937), 8. 1938), 206-11.

53Radius, Far Eastern Surver, VII (September 7, 
exporters, however, gave notice that they had turned to Central and South America where they planned to retrieve some of the losses suffered elsewhere. 54

The impulse for peace which was so strong among the American people during the mid-ithirties penetrated the thinking of commercial clrcles as vell. The editor of a leading export journal remarked that he was "constantly amazed to hear export executives say that they would rather see their trade stopned than to risk war."55 "American 'Isolationism," said the Comiercial and Financlal Chronicle, "is a policy whose wisdom is enforced by the obvious facts of the world situation." 56 on another occasion, this same journal editorialized that "no more now than in 1919 do the people of this country want to see the United States mixed up in any way with the League or entangled at any point with the politics of Europe or Asia." 57 These opinions were to persist among the members of the business community throughout the decade which preceded World War II. A survey conducted as late as 1940 revealed that three out of four business executives in the United

54 morld Unrest," United States Tobacco Journal, CXXIX (March 26, 1938), p. 4.

55"The Editor Thinks Out Loud," American Exporter, CXX (February, 1937), p. 32

56 "Concerning American Isolationism, in Commercial and Financial Chroniele, CVL (October 16, 1937), p. 2451.

57"Itching to Take a Hand," Commercial and Financial Chronicle, CXIVI (June il, 1938), p. 3718. 
States still favored either appeasement of the Japanese or letting nature take its course. 58

The apparent failure of the American businessman in China to win the sympathy and support of the commercial groups within the United States undoubtedly contributed to his lack of success in influencing American policy toward Japan. The motives which prompted financial interests in China to demand firmer measures against the Japanese were not compatible with the attitudes generally held by the commercial community at home. While few American businessmen anywhere sanctioned Japan's militaristic policies, the urge to carry on "business as usual" predisposed the majority to look with disfavor upon any suggestion of strong action which might provoke war between the United States and Japan. This view was held by the business community at large. 59

In the final analysis, a combination of both economic and political factors prevented the American commercial communty in China from exerting any appreciable degree of inf'luence over United States policy toward Japan. It was not because of successful agitation by comercial groups with vested interests in China that American diplomacy came to the defense of the Open Door. American statesmen were not concerned with the fate of a trade relationship which had never developed beyond the embryonic stage.

\section{Fortune, XXII (September, 1940), p. 73.}

59Masland, The Pacific Historical Review, XI (September, 1942), 285. 
They were concerned, however, with thwarting Japanese imperialism which threatened the balance of power in the Pacific. If Japan should go unhindered in its head-long rush for empire, the security of American possessions in the Far East would ultimately be threatened. It was to deter Japan that the United States supported the Open Door, and not because of any intrinsic regard for American commercial interests in China. 


\section{CHAPRER V}

\section{SUMUARY AND CONCLUSION}

The history of American commercial relations with China is long and complex one, dating from the earliest days of the American Republic. The interest of the United States Government in the China trade reached its zenith with the promulgation of the Open Door Policy by Secretary of State John Hay in 1900. With Hay's famous series of diplomatic notes, the concept of commercial equality within China became a "positive interest" of the United States.1 Accompanying this declaration had come the additional pronouncement that respect for China's territorial and administrative integrity was also now an official part of American foreign policy. This marked the entrance of the United States jnto the political entanglements of East Asia, 2

Such an abrupt departure from America's traditional concern for only hemispheric politics was not followed by any realistic appraisal of that must be done if national power was to be brought into balance with this now ingredient in national policy. In the years which followed, the United States Government made no effort to provide for the

$$
\text { IQuigley, p. 35. 2 }{ }^{\text {Griswold, p. } 7 .}
$$


adequate defense of the Open Door.3 The doctrine of the Open Door was, then, a virtual dead letter from its inception.

The American people evinced no greater enthusiasm for the Open Door in China than did their government. An area so far removed from the United States and seemingly so little related to domestic security was incapable of arousing any sustained interest. 4 This same lack of enthusiasm was reflected by the indifferent attitude which the majority of American businessmen displayed toward periodic efforts by government officials to interest them in direct investments in China. 5 As a consequence, America's economic stake in China remained insignificant down through the years.

Japan's conquest of Manchuria in 1931-1932 and its even more alarming assault upon China proper in 1937 sharply challenged the two fundamental principles of the Open Door. The question of engaging in war with the Japanese Empire in order to safeguard American commercial privileges in China, or to preserve the territorial integrity of the Chinese Republic, was never seriously entertained by the United States Government. No administration had ever believed that the Open Door was worth a war, and this judgement had been sustained by American public

$$
\begin{aligned}
& \text { 30sgood, p. } 79 . \quad 4 \text { Balley, p. } 289 . \\
& \text { 5quigley, p. } 36 .
\end{aligned}
$$


opinion. 6

In 1937, however, American statesmen sensed that something more was involved than the mere violation of a doctrine that had never been considered of intrinsic value to either the political or economic well-being of the United States. Japanese imperialism was on the march in Asia. If allowed to proceed unhindered, Japan might destroy the delicate balance of power in the Pacific. The American Government came to realize that its policy toward events in China must be integrated with a forolgn policy toward the world as a whole in the interest of preventing world-wide aggression.7

It had been with this larger objective in mind that Secretary of State Cordell Hull wrote to Vice-President Garner in 1937 that the interest of the United States in the Sino-Japanese conflict "far transcends in importance the value of American trade with China or Anerican investments in China; it transcends even the. . Welfare of American citizens in China. 18 A scuttling departure from the Asian mainland in the face of danger could only signify to the Japanese a complete retreat by the United States from the Pacific.9 Such encouragement must not be

6osgood, p. 62. See also Neumann, p. 148, and Griswold, p. 469.

${ }^{7}$ Chou I-kua, "The American Policy in China, 19291939" (unpublished Ph. D. dissertation, Fletcher School of Law and Diplomacy, Tufts University, 1949), p. 3.

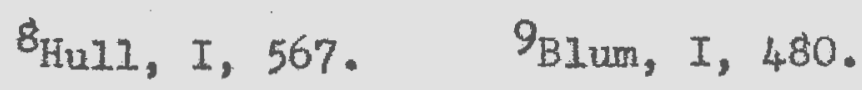


given to those who showed open disdain for "orderly processes in international relationships."10

The decision had thus been reached that Japan's ambitions in East Asia must be thwarted. Conditions pecullar to the moment made the question of method particularly difficult. American citizens with an economic stake In China noisily demanded that the United States take strong measures to stop the Japanese. The disposition of their fellow countrymen half a world sway, however, was quite different. The years after world war I had brought a deep sense of disillusionment to the American homeland. President Wilson"g League of Nations had been rejected by his own people, and the participation of the United States in the Great War itself had come to be profoundly regretted. An intense revulsion against war had elicited from the citizens of the United States a firm rosolve never again to become involved in the quarrels of foreign powers. The isolationist sentiment, never too far beneath the surface of the American mind, had been excited to now heights in the early and mid-'thirties.

This national determination to avoid forelgn wars imposed severe limitations upon those who were entrusted with conducting the foreign affairs of the United States at the time of Japan's invasion of China. Any action which might jeopardize the peace and tranquility of the nation would not be tolerated by the American people. After much 
searching of minds, United States offlcials had been forced to conclude that the only visible means of restraining Japan seemed to rest in a vigorous defense of American rights and interests in China. Yet even this feeble gesture was subject to strong criticism in the United States. Throughout 1937 and 1938, there were continuous demands to recall all Americans from China and to withdraw official protection from those who chose to remain. The Roosevelt Administration, however, persistently refused to surrender this one means at its disposal by which it hoped to restrain Japan.

The decision to invoke the principles of the Open Door had not resulted from any desire to support the material interests of American commercial groups in China. The motives of the government had been strictly political, not economic. There was nothing new in this use of American business interests in China as an instrument of national policy. The occasion for the formal announcement of the Open Door in 1900 had been the impending disinemberment of China, an event which Secretary of State John Hay had hoped to prevent. In so far as Hay thought of economic considerations at all, he had trade in mind, but his main objective was to secure a political result. 11 In the years between 1900 and World Tar I, Secretaries Knox and Lansing had both sought to interest American businessmen in various financial schemes in China for the political purpose of 
counterbalancing Russian and Japanese influence in Manchurla and China.12 Thus when the United States Government used the Open Door as a political weapon againgt the Japanese in 1937, it was only following a long historic precedent.

A study of United States policy as it evolved during 1937 and 1938 clearly refutes the clain that American comercial interests in China exerted any appreciable influence upon foreign relations. To the contrary, it is apparent that the United States Government used the presence of business interests within China for the political purpose of obstructing Japan's efforts to create a "co-prosperity" sphere in the Far East. The Department of State, moreover, frequently took steps to discourage economic activities which might benefit Japanese imperialism. When certain Japanese industrial interests attempted to secure ${ }_{\sharp} 50,000,000$ in credits from private American sources early in 1938, Washington quickly let it be known that it did not approve any such credits, and the matter was immediately dropped.13 On another occasion, several Japanese sources hinted that there would be many opportunIties for indirect Westorn investments in the subjugated areas of North China. Again the United States Government indicated that it would look with disfavor upon the

12 Griswold, pp. $469-70$.

13"Sino-Japanese War," Commercial and Financial Chronicle, CXIVIII (January 22, 1938), 483. 
provision of American capital for purposes of exploiting a conquered territory. 14 The State Department was also successful in halting the shipment of American aircraft and aerial bombs to Japan. In July, 1938, Secretary of State Hull reminded all American manufacturers of aeronautical equipment that the United States Government was strongly opposed to the sale of airplanes and equipment to nations which bombed civilian populations. Although Japan was not mentioned by name, Hashington noted with satisfaction that by November, 1938, applications for export licenses of aircraft and aerial bombs to Japan had disappeared. 15 Conmercial groups in the United States often complained against such limitations upon their activities, but they nevertheless were willing to accept the judgement of their government without any serious resistence. 16

While United States policy toward Japan was never tailored to fit the desires of American business interests in China, there is a sense in which these commercial groups did influence the subsequent course of Japanese-American relations. As the war in China dragged on, resentment against Japan mounted in the United States. Japanese aircraft continued to bomb crowded Chinese cities, killing thousands. The war which Japan had bogun demolished $1938), 235$.

14 Stewart, Far Eastern Survey, VII (October 12,

15"Sino-Japanese War," Cormercial and Financial Chronicle, CXLVIII (January 14, 1939), 164-65.

16Masland, The Pacific Historical Review, XI (September, 1942), 289. 
American churches and schools, ruined American businesses, and destroyed American lives. The brutality and disregard for American interests which the Japanese exhibited gradually angered the people of the United States.17

Growing popular indignation made possible an increasingly strong stand against Japan. By the end of 1938, the United States was no longer concernod with serupulously maintaining the outward appearance of neutiality. On December 15, the United States Export-Import Bank placed $25,000,000$ in credits at the disposal of Nationalist China. This enabled china to make vital purchases of essential war materials. In addition, the American treasury extended the Chinese-American monetary agreement of July 9, 1937, by which China was able to obtain dollar exchange against its gold reserves in New York. These were the first positive aids to the National1st Government since the Japanese invasion. 18

This material assistance to China was followed in the summer of the following year by the announcement that the United States was abrogating its 1911 commercial treaty with Japan. Formal notice that the treaty would be terminated in six nonth's time was given to the Japarese on July 26, 1939. In the judgement of the State Department, Tokyo's hostility to American interests in China did not

17 Feis, p. 1 t5.

18nU. S. Counters Japan's Hew Order in Asia," Foreign Policy Bulletin, XVII (December 30, 1938), 1. 
merit the continuance of a special commercial arrangement between the United States and Japan.19 This was a step that President Roosevelt and Secretary hull had been contemplating for some time.20 It was a measure that would have been out of the question two years before, but which now became possible in large part because of the changing climate in American public opinion.

Thus, while the initial protests of American businessmen in China did not influence the formation of the United States' response to Japan's challenge, the repeated destruction of American interests in China by a callous aggressor did succeed in working a change upon the mind of the American public. And as the attitude of Americans toward Japan stiffened, the goverment in Washington was given increased latitude in its efforts to deter Japanese imperialism in East Asia. Interference with American rights in China by the Japanese did, then, have an ultimate effect upon American policy, not as a prime mover, but as one among a growing number of grievances which the United States came to harbor against Japan. 


\section{BIBLIOGRAPHY}

\section{A. Books}

Arnold, Julean. China: A Comercial and Industrlal Handbook. T. S, Department of Commerce Trade Promotion Series No, 28.) Washington: U.S. Government Printing office, 1926.

- China Trade Facts. U. S. Department of Commerce, Bureau of Foreign and Domestic Commerce.) Washington: U.S. Government Printing Office, 1925.

Bailey, Thomas A. The Man in the Street. New York: The Macmilian Co., 1948.

Beard, Charles A. American Forelgn Pollcy in the Making, 1932-1940. New Haven: Yale University Press, 1946.

Bemis, Samuel Flagg. American Foreign Policy and Diplomacy. New York: Henry Holt Co., 1959.

- The United States as a World Power: A Diplomatic History, 1900-1955. Hew York: Henry Holt \& Co., 1955.

B1sson, T. A, American Policy in the Far East, 1931-1940. New York: Institute of Pacific Relations 1940.

Blum, John Morton. From the Morgenthau Diaries: Hears of Crisis, 1928-1938. Vol. I. Boston: Houghton Mifflin Co., 1959.

Buell, Raymond L. Isolated America. New York: Alfred A, Knopf, 1940.

Campbell, Charles S., Jr. Special Business Interests and the Open Door Policy. New Haven: Yalo University Press, 1951.

Clyde, Paul H. The Far East: A Histcry of the Impact of the West on Eastern Asia. New lork: FrenticeHall, Inc., 1948. 
Drummond, Donald $F$. The Passing of American Neutrality, 1937-1941. Ann Arbor: The University of Hichigan Press, 1955.

Feis, Herbert. The Road to Pearl Harbor. Princeton: Princeton University Press, 1950.

Grew, Joseph C. Ten Years in Japan. Hew York: Simon \& Schuster, 1944.

Griswold, A. Whitney. The Far Eastern Poltcy of the United States. New York: Harcourt, Brace \& Co., 1938.

Harrison, Forman. Changing China. Now York: Crown Publishing Co., 1948 .

Hull, Corde11. The Memoirs of Corde11 Hul1. Vol. I. New York: The Macmilian Co., 1948.

Ickes, Harold L. The Secret Diary of Harold L. Ickes. Vol. II. New York: Simon \& Schuster, 1954.

Johnstone, William C. The United States and Japan's New Order. New Iork: Oxford University Press, 1941.

Langer, William L., and Gleason, S. Everett. The Challenge to Isolationism, 1937-1940. New York: Harper \& Bros., 1952.

Millis, Walter. Arms and the State. New York: The Wentieth Century Fund, 1958 .

Neumann, Wiliiam L. "Ambiguity and Ambivalence in Ideals of National Interest in Asia," Isolation and

Security, Alexander DeConde (ed.). Durham, Morth Carolina: Duke University Press, 1957.

Osgood, Robert E. Ideals and Self-Interest in America's Foreign Relations. Chicago: The University of Chicago Press, 1953.

Perkins, Dexter. "The Department of State and American Public Opinion," The Diplomats, 1919-1939. Edited by Gordon A. Crat $\mathrm{g}$ and Felix Gilbert. Princeton: Princeton University Press, 1953.

Quigley, Harold S. Far Eastern War, 1937-1941. Boston: World Peace Foundations, 1942.

Remer, C. F. Foreign Investments in China. New York: The Macmilian Co., 1933. 
Smith, Charles W. Publie Oplnion In Depocrecy. Wew Iork: PrenticonaII, Ine.t. 1942.

StImsen, Henry I., and Bundy, HeGeorge. On Active Service in Peace and War. Wow Tork: Harper \& Bros., 1947.

Ing-11n Hat Ghina and Foreign Capital. Ghungking, (hinal ihine Institute of Pacific Relations, 1945.

B. Articles and Periodicals.

"American Chamber at Tientsin Warns U. S. Bualneamen,"

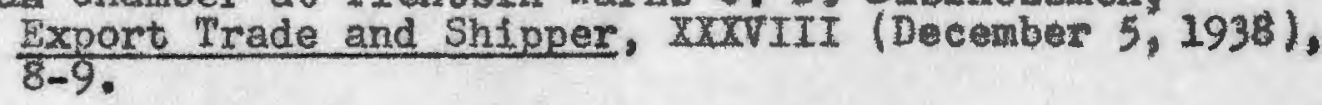

Ballantine, Joseph W, Mukden to Pearl Harbor: The Forolgn Policies of Japan," Foreign Affalng, XXVII (Juiy, 1949), 651-664.

Blason, T. A, "American Pollcy in the Far East," Foreign Pol1cy Reports, XII (February 1, 1937), 270-280.

"Stragele of the Power: in China" Poraign Pallat foports, XII (August 1, 1936), 122-132.

Bloch, Rurt. NAlien Landownership Voreus Open Door in

Ching," Far Eastern Survey, VII (August 24, 1938), $195-99$.

- Chinese-American Economio Relations and the Waw " Far Eastern Survey, VIII (Jenuary 19, 1939), $13-17$.

The China Weekly Review, 1937.

"Concerniag American "Igolationism," Commercial and Financtal Chronfele, CVL (Óctober 16, 1937), 2449-2451.

"The Editor Minks Out Loud," Ameriean Exportex, CXX (February, 1937), 31-33.

Farloy, Mirlan S, "America's Stake in the Far Rast, I Trade" Far Eastern Surver, V (July 29, 1936), $161-170$.

Fortune, XxII (September, 1940), 72 fr.

- Itching to Teke a Hand, Compercial and Finanelal Chroulale CxuI. (June 11, 1938), 3716-It. 
"Little Threat to U. S. Investments in China," The Financial Wor1d, LXVII (September 1, 1937), 8.

Lockwood, William $\omega_{.}, \mathrm{Jr}$. "American Neutrality and the Far East," Far Eastern Survey, VI (September 15, 1937), 211-18.

- 'America's Stake in the Far East, II: Investments," Far Eastern Survey, V (August 12, 1936), $175-203$.

"North China and the United States Cotton Trade," Far Eastern Survey, VII (May 18, 1938), 115-18.

Hasland, John W. "Commercial Influence Upon Far Eastern Folicy, 1937-1941," the Pacific Historical Review, XI (September, 1942), 281-99.

Popper, David H. "Progress of the Sino-Japanese Conflict," Foreign Policy Reports, XIV (May 15, 1938), 50-60.

"The viestern Powers and the Sino-Japanese Conflict," Foreign Policy Reports, XIV (August 1, 1938), 110-20.

Radius, Walter A. "The Play of Petroleum Forces in the Far East," Far Eastern Survey, VII (September 7, 1938), 205-11.

"United States Trade and the Sino-Japanese War," Far Eastern Survey, VII (January 5, 1938), 1-7.

"Sino-Japanese War," Commercial and Financial Chronicle, CXLVIII (January 22, 1938), 483-84.

"Sino-Japanese Viar," Commercial and Financial Chronjele, CXLVIII (January 14, 1939), 164-65.

Stewart, John $\mathrm{R}$. "Foreign Investments in lanchuria," Far Eastern Survey, IV (June 5, 1935), 81-85.

"The War and Western Interests in North China," Far Eastern Survey, VII (October 12, 1938), 229-35.

Taylor, Paul B. "America's Kole in the Far Eastern Conflict, "Forelgn Policy Reports, XIII (February $15,1938\}, \overline{278-88}$.

"U. S. Counters Japan's New Order in Asia, "Foreign Policy BuIletin, XVIII (December 30, 1938), I-2.

"What's Our Stake in China," Business Wook, August 7, 1937, pp. 14-15. 
"World Unrest," United States Tobacco Journal, cxxIX (March 26, 1938), 4 .

C. Public Documents

U. S, CongressionaI Record. Vols. LXXXI, LXXXII, LXXXIII.

U. S. Department of State. Papers Relating to the Foreign Relations of the United States: Japan, 1931-1941. Vo1. I. Washington: United States Government Printing office, 1943.

D. Unpublished Materiel

I-kua, Chou, "The American Policy in China, 1929-1939." Unpublished Ph. D. dissertation, Fleteher Sehool of Law and Diplomaey, Tufts University, 1949. 